WHOI-89-7

CRC-89-1

\title{
Coastal Research Center Woods Hole Oceanographic Institution Report for the Period March 1986 - July 1988
}

by

Bruce W. Tripp

Woods Hole Oceanographic Institution

Woods Hole, Massachusetts 02543

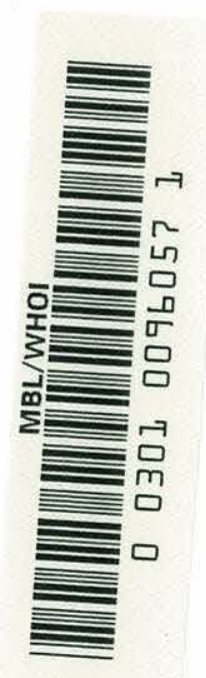

March 1989

\section{Technical Report}

Support was provided by the Richard King Mellon Foundation, the Andrew W. Mellon Foundation, the Donaldson Charitable Trust, and by the Mobil Foundation.

Reproduction in whole or in part is permitted for any purpose of the

United States Government. This report should be cited as:

Woods Hole Oceanog. Inst. Tech. Rept., WHOI-89-7. CRC-89-1.

Approved for publication; distribution unlimited.

Approved for Distribution:

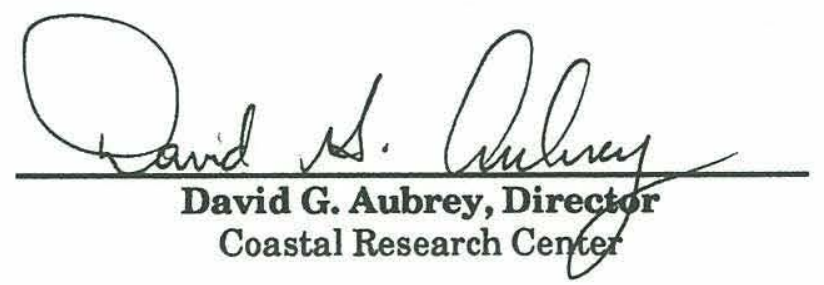


$\begin{array}{ll}\text { DEDICATION } & 3\end{array}$

ACKNOWLEDGMENTS

$\begin{array}{lc}\text { INTRODUCTION } & 6\end{array}$

1. BACKGROUND 6

2. CRC ORGANIZATION

$\begin{array}{lr}\text { MAJOR ACTIVITIES } & 10\end{array}$

1. Impacts of Global Climate Change on the Coastal Zone 10

2. ASSIMIlative CaPaCity

3. COASTAL INSTRUMENTATION A. FLUMES 15

B. CURRENT PROFIler $\quad 15$

4. RAPID RESPONSE

A. Chernobyl 16

B. MASSACHUSETTS Whale MORTALITY 17

5. GEORGES BANK BOOK 18

$\begin{array}{lr}\text { STUDENT SUPPORT } & 19\end{array}$

VISITORS

1. SEMINARS, ViSitorS, APPOINTMENTS 22

2. B.H. KETCHUM AWARD 25

$\begin{array}{lr}\text { SYMPOSIA, WORKSHOPS } & 26\end{array}$

CRC FACILITIES $\quad 27$

1. Coastal Research Laboratory 27

2. FLUME INSTRUMENTATION

3. SMALL BOAT FLEET

4. MisCellaneOUS EQUiPMENT

APPENDICES $\quad 32$

1. CRC PUblication List $\quad 32$

2. TABLE OF CONTENTS 36

A.GEORGES BANK 36

B.HYDRODYNAMICS AND SEDIMENT DYNAMICS OF TIDAL INLETS 38

C.RESPONSES OF MARINE ORGANISMS TO POLLUTANTS 39

3. CRC RESEARCH AWARDS 40 


\begin{abstract}
Activities of the WHOI Coastal Research Center during the period of March 1986 to July 1988 are briefly described. Major activities during this period include: 1. global climate change, 2. assimilative capacity, 3. coastal instrumentation and 4. rapid response. During this period the Georges Bank book was completed and published by MIT Press.

Continuing emphasis is placed by $\mathrm{CRC}$ on fostering interdisciplinary and multi-institutional interactions. This emphasis is implemented through support of workshops, guest investigators, speakers and students.
\end{abstract}




\section{Preface}

This report describes the activities of the WHOI Coastal Research Center for the 28-month period through July 1988 . During this period, two major projects were completed and a change in Center Directors occurred. The Georges' Bank book has been published with accompanying praise, and two experimental flumes are now operational for studies of coastal processes. These two projects have been major activities for CRC; with their completion we have an opportunity to expand into new arenas.

Our activities in coastal science come at a critical time. Increasing demands on the utilization of the coastal oceans are pushing the limits of our scientific understanding. To respond to these increasing and conflicting use demands, science must make rapid leaps forward in areas such as global climate change, ocean pollution, nutrient input to coastal waters, toxic shellfish poisoning, and coastal erosion, for example. How effectively man manages these fragile coastal resources depends in large part on the ability of science to provide definitive guidance to policy and management formulators.

As we move into the future, the Coastal Research Center will continue to emphasize our research strengths in the coastal ocean and to facilitate the interaction between science and policy. The primary emphasis of CRC activities will be to undertake basic research which can clarify both the natural and human-induced variability in coastal processes in order to understand these processes better and to assist in the prediction of future states of the coastal environment. The success of CRC is due to the enthusiasm and hard work of scientists and technical staff in coastal research at WHOI and to the generous support given to this effort by private donors and foundations.

I greatly appreciate the efforts of those who preceded me, and I look forward to leading the $\mathrm{CRC}$ into new and exciting areas of research.

Dr. David G. Aubrey

Director, Coastal Research Center 


\section{DEDICATION}

\section{WILLIAM D. GRANT \\ September 22, 1946 - October 7, 1986}

A report of the Coastal Research Center covering this time period cannot be written without noting a sad event in October 1986 - the passing of Dr. William D. Grant. Bill's infectious enthusiasm for life and research remains an inspiration not only for CRC staff but also for his colleagues and friends in the marine sciences and ocean engineering communities worldwide.

Bill Grant was associated with the Coastal Research Center from its beginnings, working energetically in the design and construction of our 17-m flume and as Chairman of the CRC Advisory Committee. Bill's energy, enthusiasm and demanding professional standards leave those who remain behind with a special goal: uncompromising excellence in all that we undertake.

A memorial plaque dedicated to Bill has been located outside of the Coastal Research Laboratory of the CRC. This plaque contains the inscription:

"In fond memory, William D. "Bill" Grant, Scientist, Engineer, Colleague and Friend, whose wisdom, dedication and boundless energy were and will continue to be an inspiration to fellow scientists, students and all others who were fortunate enough to know him." 


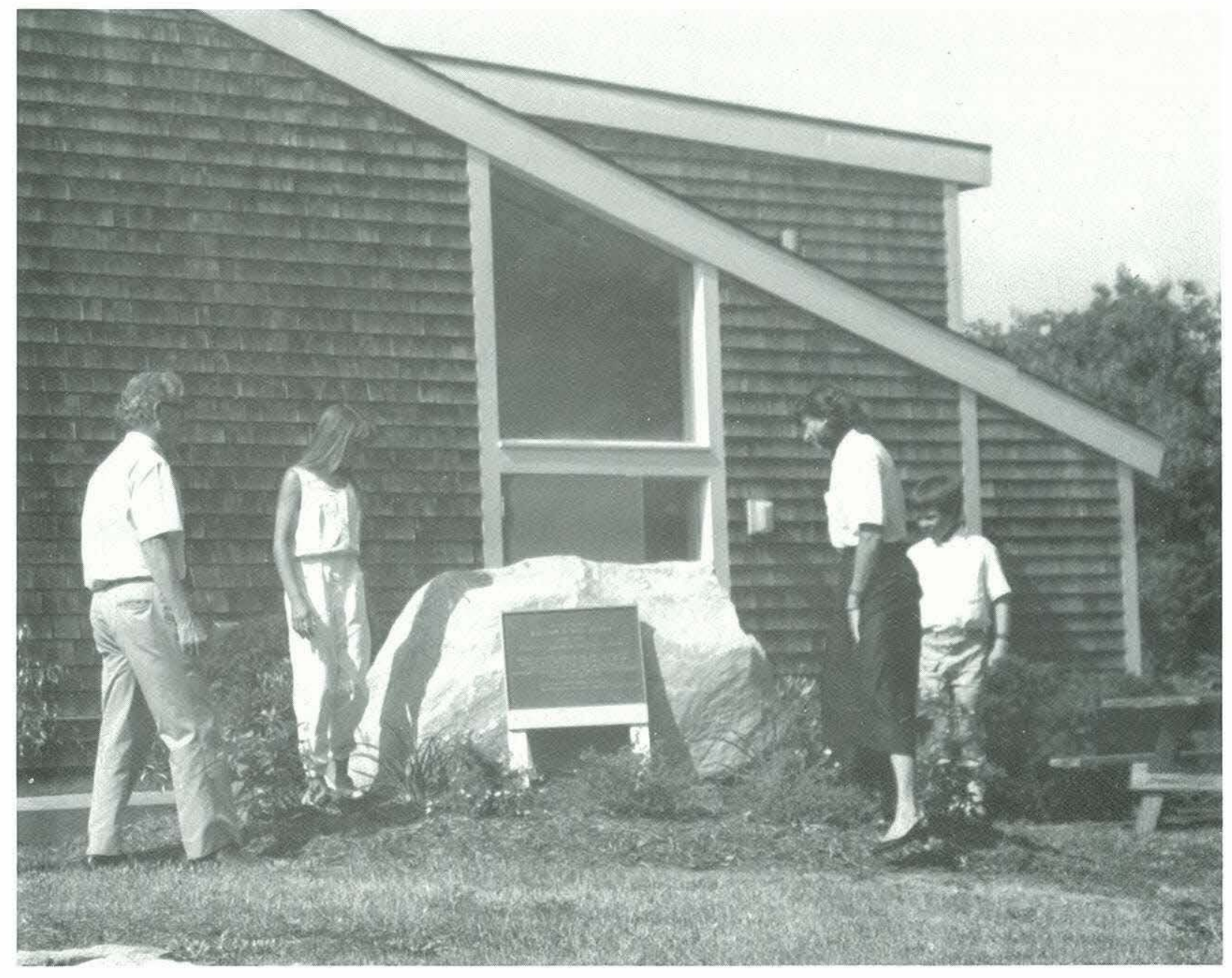

Bill Grant's family unveils the memorial plaque while Woods Hole Oceanographic Institution's director, John Steele, looks on. 


\section{ACKNOWLEDGMENTS}

The work of the WHOI Coastal Research Center has been generously supported by several private foundations; for this support we are grateful.

A Richard King Mellon Foundation grant has provided essential support in several CRC project areas including student research, rapid response, assimilative capacity and global climate change.

The Andrew W. Mellon Foundation has been a generous and long-term supporter of $\mathrm{CRC}$; its unrestricted funds have helped bridge a recent transition into new project areas.

Support from the Donaldson Charitable Trust has permitted expanded studies into toxic dinoflagellate blooms and enables CRC investigators to respond rapidly to coastal catastrophes in order to obtain initial data that would otherwise be lost.

The Mobil Foundation, another long-term CRC supporter, has continued to provide programmatic support for coastal research programs.

Dr. Donald Rhoads and Dr. Larry Boyer of Yale Univesity donated the racetrack flume to the Coastal Research Center, and by doing so have expanded our in-house research capabilities.

Dr. John W. Farrington guided the CRC with enthusiasm and wisdom during the past several years. We appreciate his leadership during his tenure as CRC Director, but this appreciation grows as we learn again and again how great a contribution he made during that time.

Pam Barrows, CRC Administrator, typed this report with her usual competence and patiently retyped major portions as comments on preliminary drafts were incorporated. 


\section{Introduction to the CoAstal Research Center}

\section{Background}

The Coastal Research Center (CRC) of the Woods Hole Oceanographic Institution was established in late 1979 to meet several research needs identified during a series of staff seminars held in 1978 and 1979. These needs include:

- improved communication of research results between disciplines,

- more formal interdisciplinary interactions in order to effectively tackle key coastal research problems,

- facilities for experimentation, and

- unrestricted funds to initiate new, interdisciplinary research ventures or to act as the "glue" binding together ongoing coastal research projects.

Historically, the Institution's efforts have been popularly identified as oriented toward the open ocean. The establishment of the Coastal Research Center was intended not to reverse this perception, but to facilitate the continuing coastal research efforts which have always been an integral and important part of the Institution's activities. Early research of the Institution focused on the Gulf of Maine, Georges Bank and the Gulf Stream, although this research quickly expanded into all areas and depths of the world's oceans. These early efforts are exemplified by Dr. Henry Bigelow's pioneering research on the hydrography, plankton and fishes of Georges Bank. Bigelow set the standards for modern oceanographic research; by his emphasis on interdisciplinary studies he unwittingly established the underlying philosophy of the Coastal Research Center. Another example which serves to illustrate this commitment is the co-sponsorship, with The Institution of Ecology, of the Workshop on Critical Problems of the Coastal Zone, held in Woods Hole, Massachusetts from 22 May to 3 June, 1972, under the guidance and leadership of the late Dr. Bostwick H. Ketchum. The conference and its proceedings, The Water's Edge: Critical Problems of the Coastal Zone (MIT Press, 1972) are widely credited with maintaining the momentum and focusing the direction for present national coastal management policy, as well as research efforts. The working definition of the coastal zone that evolved from that meeting remains valid and is used to guide the Coastal Research Center's sphere of activities:

"The coastal zone is a band of variable width which borders the continents, the inland seas, and the Great Lakes. Functionally, it is the broad interface between land and water where production, consumption, and exchange processes occur at high rates of intensity. Ecologically, it is an area of dynamic biogeochemical activity but with limited capacity for supporting various forms of human use. 
Geographically, the landward boundary of the coastal zone is necessarily vague. The oceans may affect climate far inland from the sea. Ocean salt penetrates estuaries to various extents, depending largely upon geometry of the estuary and river flow, and the ocean tides may extend even farther upstream than the salt penetration. Pollutants added even to the freshwater part of a river ultimately reach the sea after passing through the estuary.

The seaward boundary is easier to define scientifically, but it has been the cause of extensive political argument and disagreement. Coastal waters differ chemically from those of the open sea, even in areas where man's impact is minimal. Generally, the coastal water can be identified at least to the edge of the Continental Shelf (depth of about 200 meters), but the influence of major rivers may extend many miles beyond this boundary. For the purposes of the Coastal Zone Workshop, the seaward boundary has been defined as the extent to which man's landbased activities have a measurable influence on the chemistry of the water or on the ecology of marine life."

Today, coastal researchers recognize that there are important interactions between the open ocean and the coastal ocean that influence the biology, chemistry, geology and physics of each. These interactions are reflected in such phenomena as upwelling, eddies impinging on the shelf edge, transport of sediments onto the continental slope and rise and into canyons, and tides propagating across the shelf slope and break. The seaward boundary of the coastal zone becomes more vague as we increase our knowledge of the coastal ocean. This merger of open ocean and coastal ocean phenomena is reflected in the philosophy and projects undertaken within the Coastal Research Center.

An essential component of coastal research conducted under CRC auspices is the translation of research results into information that is useful for research management decisionmaking. We also continue to ascribe to the views of the importance of the environment set forth by Ketchum and co-workers:

"The coastal environment constitutes a complex ecosystem that is an important and unique resource of our nation and that must be maintained for the benefit and use of mankind. ... A balance of use, conservation, and preservation of the coastal zone should be maintained so as to optimize man's use of coastal resources through the long term future, which requires that the natural environmental processes on which most of the long term continuing uses depend must also be maintained."

The objective of the Coastal Research Center of the Woods Hole Oceanographic Institution is to conduct basic scientific research, contributing to an ever-expanding base of knowledge and improved understanding of the coastal ocean, its physics, chemistry, biology and geology. This 
improved understanding will also provide a scientific basis for wise management of coastal resources. Our strategy for accomplishing this objective is to encourage the cross-fertilization of interdisciplinary groups of scientists at the Institution, and also to support multi-organizational (industry, government, academic) and multi-national efforts as appropriate. The CRC seeks to aid individual researchers of coastal problems by providing intellectual forums that encourage communication; research facilities; and services. We have been, and intend to continue to be, active at the science-policy interface.

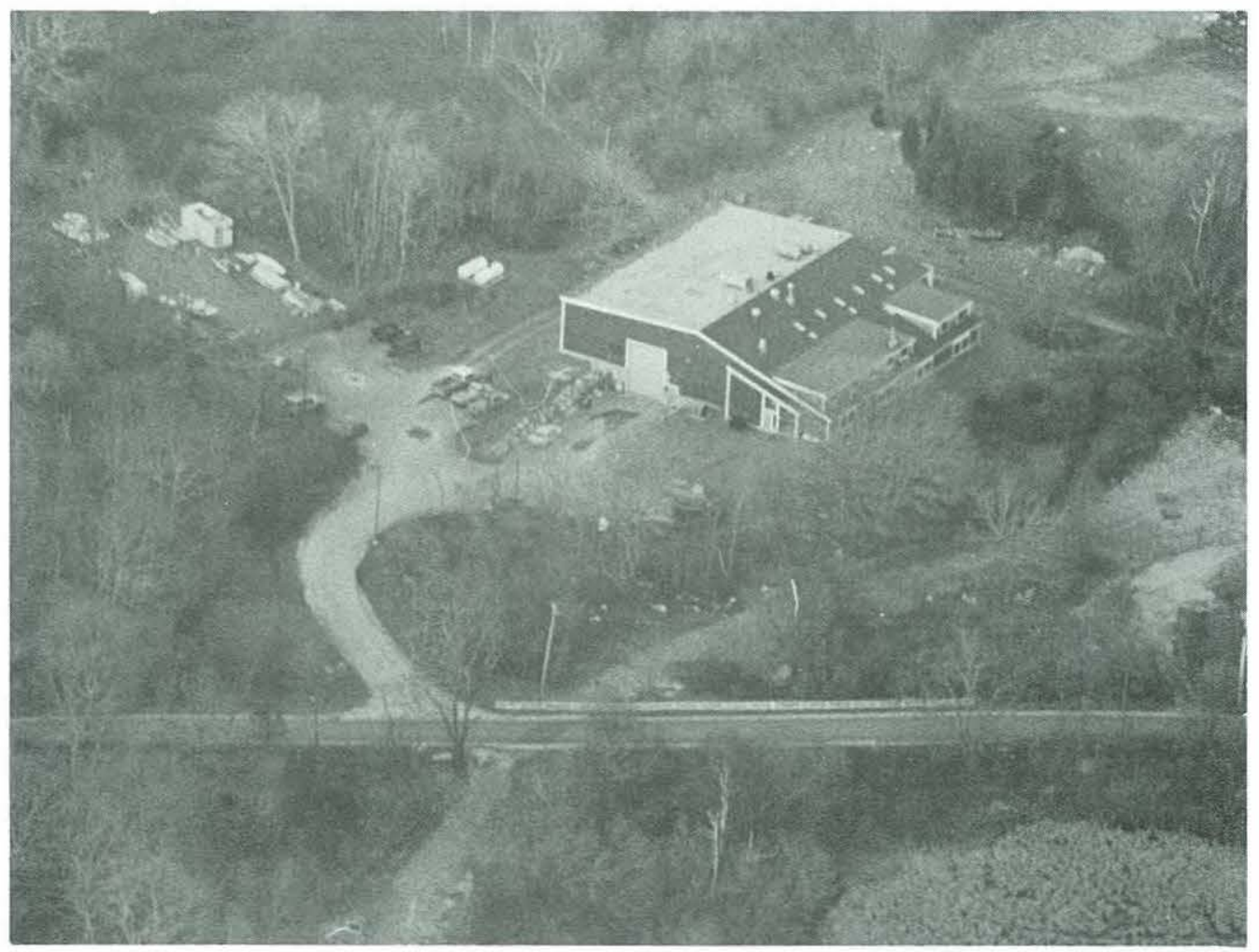

\section{CRC Organization}

Research within the Center is carried out by scientists, staff, and students from the five scientific departments of the Institution (Physical Oceanography, Geology and Geophysics, Biology, Chemistry, and Ocean Engineering) and by Guest Investigators. These researchers are active in Center activities for varying periods of time, as the Center has no permanent scientific staff except the Center Director. Technical staff, research assistants, and administrative personnel are assigned to the Center for periods of time as needed for specific projects. The Center serves as a home for visiting scientists and post-doctoral investigators who are invited to the Institution to participate in specific research projects. 
The Center Director is David G. Aubrey, who took over the leadership of the Coastal Research Center from John Farrington in May, 1987. John Farrington ably guided the Center through its critical formative years and played a major role in establishing CRC as an integral component of the Woods Hole research community. The change in Director does not imply a fundamental change for the CRC, but rather we expect a continued maturing process that builds on the strong base laid down by others.

The Center Director is responsible for CRC activities and works with the advice of the Advisory Committee. He reports to the WHOI Director, John Steele, and to the WHOI Associate Director for Research, Derek W. Spencer. Assistance for the operation and administration of the Center is provided by Pam Barrows and Roy Smith.

An Advisory Committee with representation from each of the departments, the Marine Policy Center, and the WHOI Sea Grant Program, provides advice for the Center Director in areas of research projects, expenditures, and experimental facilities. In addition, committee members function as liaison with their own departments, and are expected to develop and maintain a dialog between CRC and departmental staff.

Advisory Committee membership includes:

Donald M. Anderson, Biology (Chairman)

Wayne R. Geyer, Ocean Engineering

David C. Chapman, Physical Oceanography

James M. Broadus, Marine Policy Center

John D. Milliman, Geology and Geophysics

Edward R. Sholkovitz, Chemistry

Alan W. White, Sea Grant (ex officio)

During the period of this report, several Advisory Committee members completed their term of appointment:

Kenneth H. Brink, Physical Oceanography

Cheryl Ann Butman, Ocean Engineering

John W.H. Dacey, Biology

The Center Director and current Advisory Committee members gratefully acknowledge the contributions made by these former committee members. We also specifically acknowledge the hard work on behalf of the Center by Susan Kadar, who ably functioned as CRC Administrator during John Farrington's tenure as Director. 


\section{MAIOR ACTUVITUES}

The CRC programmatic elements focus on the natural and human-induced variability in our global coastal environments. Natural variability increases the difficulty of predicting future states of this coastal environment, since the variability covers many space and time scales associated with natural processes. Superimposed on this natural variability is the impact of human activities on the coastal zone, an impact that can only increase as development pressures and multiple use conflicts increase. The primary emphasis of Coastal Research Center activities will be to provide basic research clarifying both natural and human-induced variability in the coastal zone, research that will aid in management, policy, and mitigation analysis for the entire globe.

The CRC program will serve the useful purpose of providing basic research needed to separate, where possible, the effects of natural versus human impacts. Such a distinction is required if we are to increase our predictive capabilities in this environment.

Four major programmatic tasks make up the primary focus of CRC emphasis over the next few years. Each addresses a separate aspect of the global change issue. Some of these tasks are new, but some build on the proven strengths of the Coastal Research Center's research program developed during the past years. A fifth major CRC activity, the Georges Bank Book, has been completed and is summarized below.

The four major CRC programmatic elements follow:

\section{Impacts of Global Climate Change on the Coastal Zone}

Global climate change is the norm, rather than the exception, in earth's history. Over the past century, however, a new cause of global change has emerged: human impact. Human impact comes about as a result of trace gas emissions, modification of the biosphere, and alteration of the hydrosphere (groundwater, streams, lakes, etc.). These human impacts will effect changes in surface temperatures, precipitation, water temperature, storm climate, groundwater recharge, and so on. To predict correctly what some of these impacts of human intervention might be, we must be able to interpret correctly the historical record, and to improve our understanding of the physics and chemistry governing these systems.

Our emphasis on global change will address those aspects particularly impacting coastal environments: sea levels, circulation of bays and estuaries, precipitation (both absolute amounts and distribution), groundwater recharge, storm climatology, and so on. These impacts will be more severe in some areas than others; the socio-economic impact of these changes will be a function of how well we can predict the magnitude, geographic distribution, and timing of these changes. 


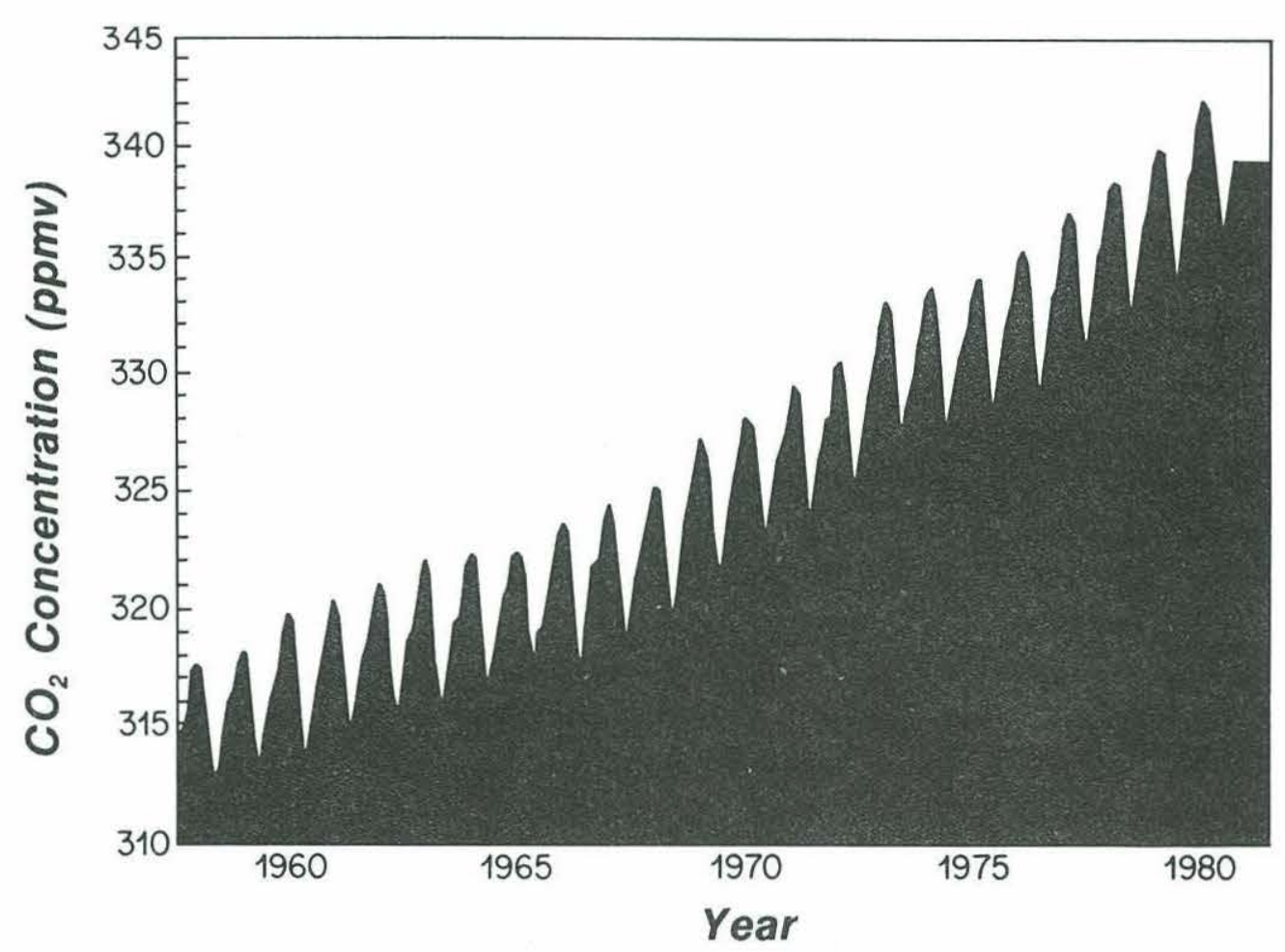

CRC research activities examining the impacts of climate change on the coastal zone have been varied. One area of investigation has been the examination of relative sea-level changes arising from the combination of land subsidence and ocean level changes. In a series of articles, Aubrey and Emery have studied evidence from tide-gauge records from around the world to provide hypotheses for causes of local sea-level rise. Results of these investigations clearly show that neo-tectonism from a variety of causes (glacial rebound, sediment and water loading, plate tectonics) contributes to local sea-level rise, a factor that must be taken into account when anticipating impacts from future climate change. Although these effects have also been described elsewhere, these recent studies are global in coverage and demonstrate the pervasiveness of contamination of tide-gauge records by land-level movements.

Related to the above studies is research in the major deltaic areas of the world, where coastal stability is a function of the balance between sediment consolidation, crustal flexure, and de-watering processes causing land submergence, and sedimentation that tends to maintain a relatively constant elevation. In delta areas, the potential for submergence is high if this balance is not maintained. In the Nile River delta, for instance, the completion of the High Aswan Dam in the mid-1960's has resulted in a drastic reduction in sediment supply to the shoreline and delta. Resulting massive shoreline erosion (up to several kilometers in some areas) and increased salt water intrusion into the local aquifers has been observed. The Chao Phrya River delta in Bangkok 
exhibits a related phenomenon. The withdrawal of massive volumes of drinking water from aquifers beneath the city has accelerated sediment consolidation, leading to sinking of the land in some parts of the city at a rate of up to $10 \mathrm{~cm}$ per year (100 times the present rate of sea-level rise). Since the city is situated just about one meter above sea level, this submergence rate has immediate implications!

Another study pertaining to climate change impacts on the coastal environment focusing on circulation and sediment transport in the small-scale lagoons and estuaries of the world that have only small freshwater input. These small systems, usually only a few kilometers in length, strongly distort the ocean tide as it propagates into shallow waters. The result is that flood tide is either significantly longer or shorter in duration than ebb tide, causing the lagoon or estuary to be a source or sink of sediment to the nearshore region. As sea level rises in response to climate change, the hydrodynamics of these systems will evolve, so they become either more or less efficient at trapping or bypassing sediment. Previous research had suggested that these shallow embayments would tend to become more stable (last longer) with rising sea level; results of present research shows that the behavior of the systems is strongly dependent on the shape of the embayment. In some systems, existing trapping or bypassing of sediment will become accentuated, whereas in other systems, this behavior will be weakened. The study illustrates the dangers of overly simple answers to complex climate change questions.

\section{Assimilative Capacity}

Assimilative capacity has been an area of emphasis of the CRC for the past several years, concentrating on such issues as effects of elevated levels of PCB's in Buzzards Bay. It has been an enormously successful program, and one that has attracted broad attention to our efforts. We propose to continue this assimilative capacity program, addressing the issues of natural variability in these systems as compared to human impacts and changes. The emphasis could be centered around loading of our coastal zone with byproducts (material and otherwise) of human activities (industrial, trade, military, and private). How do these activities alter natural processes? How might these alterations continue or evolve in the future as development pressures escalate at the same time regulatory pressures increase?

A regional understanding of currents, circulation, sediment transport, and contaminant bioavailability is essential for an assessment of a wide variety of coastal issues such as outfall siting, fisheries recruitment, toxic algal bloom dynamics and dredge spoil disposal. Although there have been individual short-term programs to address transport processes in some areas, there has been no comprehensive effort to map and understand these processes in coastal areas on a regional, long-term basis. Many of the recent studies designed to address specific environmental questions have been site-specific and suffered from lack of a regional perspective. With increasing use of 
coastal resources, establishment of a long-term program to provide a regional description of the currents and circulation is essential. An understanding of the physical regime is also critical for studies of biological and chemical processes.

In order to clarify issues addressed in this CRC programmatic element, an example is provided here. Ongoing research in Buzzards Bay and New Bedford Harbor by Dr. Judith McDowell Capuzzo as part of a joint WHOI-Coastal Research Center-Sea Grant effort, provides an excellent opportunity to investigate the bioavailability, bioconcentration, and biological effects of organic contaminants in marine bivalve molluscs. The history of contaminant inputs to New Bedford Harbor has been carefully documented as a series of disturbances. Inputs of PCB's, heavy metals, and petroleum hydrocarbons are well-described, and the fates of these contaminants have been examined from the perspective of chemical modifications, distributions, biogeochemical cycling, and physical transport of contaminants within the Acushnet River Estuary and in the outer regions of Buzzards Bay.

Dr. McDowell Capuzzo and colleagues, including former CRC Director John Farrington have recently completed an extensive field experiment assessing the effects of PCB's, PAH's, and trace metals on populations of the common blue mussel (Mytilus edulis) transplanted to New Bedford Harbor for one year. Samples taken on a bi-weekly basis and analyzed by physiological, biochemical, and histological techniques were used to evaluate the effects of chemical contaminants on growth, energetics, and reproduction of caged mussels. Biological measurements were correlated with chemical data on body burdens of PCB's, PAH's, and trace metals, including an analysis of seasonal variability in contaminant distributions related to reproductive and metabolic activities.

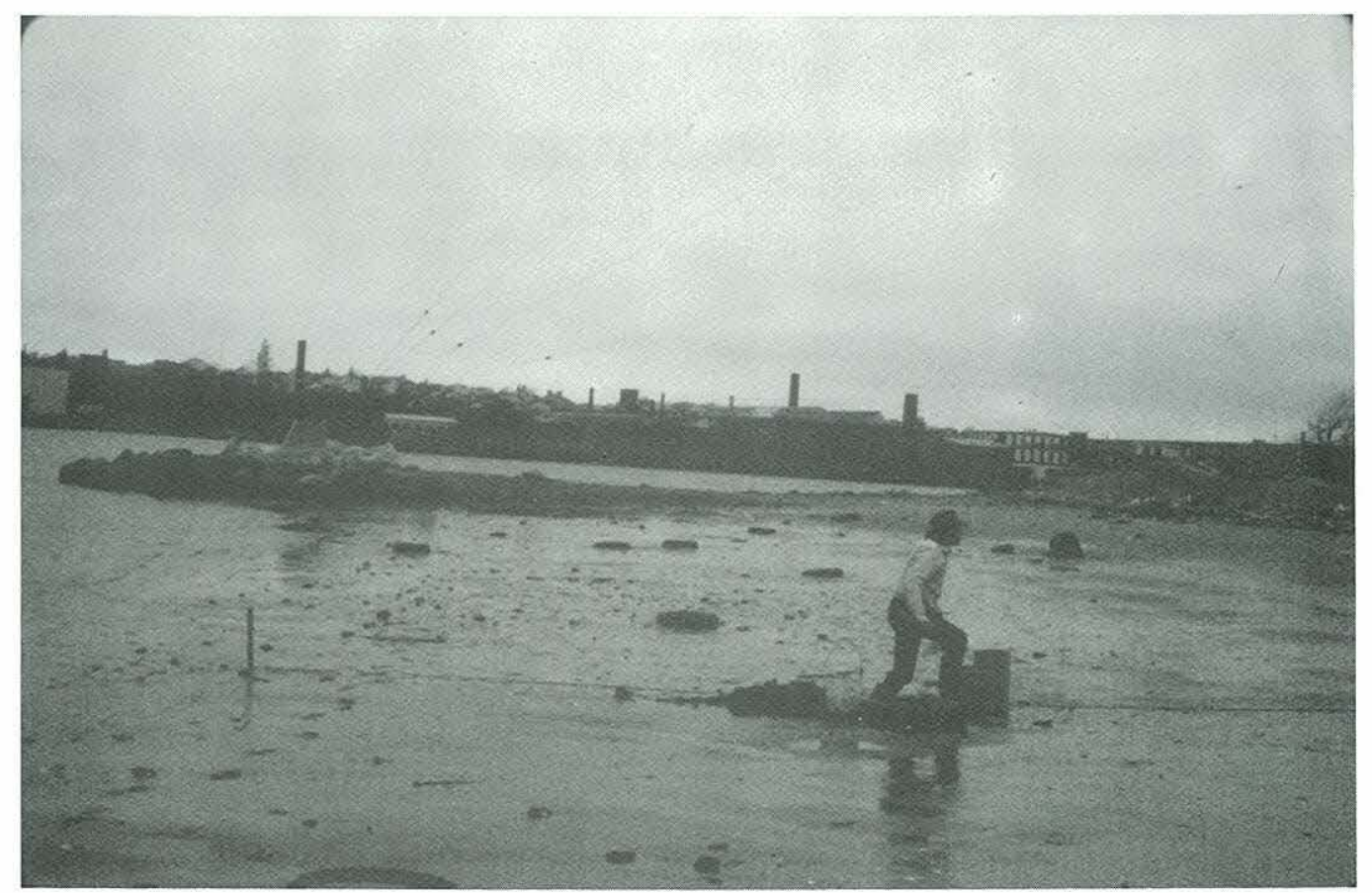


Mussel transplants in New Bedford Harbor show uptake of PCB's and PAH's to exceedingly high concentrations $\left(10^{-6} \mathrm{~g} / \mathrm{g}\right.$ dry weight range). Distribution patterns of PAH's are consistent with our general view of the bioconcentration of organic contaminants in marine organisms. The major factors controlling the distribution of PCB's and PAH's in mussels are the relative concentrations of individual contaminants in ambient waters, modified to some extent by differences in partitioning between organisms and water, and seasonal variations in lipid content. Fluctuation in contaminant distributions are associated with reproductive organ development and spawning activity and may be reflected in selective partitioning within specific tissues and possibly specific lipid pools.

Conditions indices and scope for growth estimates (two measurements of physiological condition) for mussels at New Bedford Harbor are lower than values measured from mussels at other stations during the pre-spawning period. Scope for growth measurements are positive during early gametogenesis (November - December) and just prior to spawning as populations take advantage of the spring phytoplankton bloom. Values are negative during the spawning period, indicating energy expenditures to the production and release of gametes. The two components of the mussel energy budget which most strongly influenced the observed decline in scope for growth at the New Bedford Harbor station were a decrease in the amount of carbon ingested and assimilated, and increased respiratory expenditures. These analyses provide an in situ evaluation of exposure and bioavailability of contaminants at New Bedford Harbor and other stations along the coast of Cape Cod, as well as an integration of a suite of whole organism and physiological measures for estimating survival and reproductive potential in response to contaminant perturbations.

Although the rubric of assimilative capacity is a broad one, it is an excellent one for continuation. We will place an emphasis on coastal bays and estuaries to provide some focus for this effort, although other projects will continue in the deeper waters of the coastal zone.

\section{Coastal Instrumentation}

The history of coastal research has been punctuated by new insights brought about in part by advances in our observational or analytical capabilities. Improved sensors, techniques, and observational platforms have increased our abilities to perform synoptic, accurate, long-term studies of the coastal zone. Examples include satellite oceanography, in situ sensors for physical and chemical parameters, and laboratory systems. Funding for such instrumentation development has been sporadic from federal sources, leaving many such instruments underdeveloped or only partially developed. At times it might be appropriate to fund instrumentation programs of general use for the coastal oceanographic community where other funding sources are inadequate or not available. Examples include: 
- general purpose equipment for interdisciplinary research

- $\quad$ high quality, one-of-a-kind laboratory equipment (such as flumes)

- workshops on instrumentation developmental needs

- $\quad$ seed monies for proof-of-concept design and mock-up for later funding by major agencies

- intercomparisons or calibrations between various instrument systems.

These efforts represent a continuation of past CRC activities. For instance, instrumentation was one of the prime areas envisioned when the CRC first was established. The construction of the 17-m flume in CRL was funded through CRC. A major current meter intercomparison/ evaluation was funded partly through CRC. Given this history and the difficulty of deriving conventional funding for these instrument systems, coupled with their importance in providing the advances of insight necessary for driving innovative science, the instrumentation effort must proceed as a primary task within our programmatic plans at CRC for the next few years.

\section{A. Flumes}

The Center provides experimental facilities for laboratory and field research into coastal processes. The interdisciplinary focus of the $\mathrm{CRC}$ is demonstrated by the recent completion and utilization of two circulating water flumes which are used for cross-disciplinary research. These flumes are discussed in detail in the CRC Facilities section of this report.

\section{B . Current profiler}

The CRC funded in part ,the acquisition of a $1.2 \mathrm{mHz}$ Acoustic Doppler Current Profiler for studies of nearshore circulation. The unit is capable of in situ or shipboard profiling and has a vertical range of $30 \mathrm{~m}$ with a $1 \mathrm{~m}$ resolution. The current profiler is stored and maintained by the WHOI Ocean Engineering Department and is available for use by CRC investigators on an as available basis.

\section{Rapid Response}

When environmental catastrophes occur, a rapid, decisive scientific response is called for, yet funding for such response is impossible to obtain through conventional funding channels in a timely fashion. By the time conventional funding becomes available, the opportunity for scientific observation is often past or rapidly retreating. A Rapid Response program is a continuing major task in our CRC programmatic activities.

CRC has in the past supported Rapid Response efforts, including studies of storm impacts on coastal zones, major flooding in China, oil tanker grounding on a coastal Cape Cod beach, and aftermath of the Chernobyl accident centered on Black Sea studies. Thus the precedent has been established, and the utility of such a program is clear. The CRC Rapid Response program gives us 
an opportunity to collect the samples immediately following an oceanographic event allowing us to unravel complex processes that would otherwise remain obscure.

\section{A. Chernobyl nuclear power plant disaster}

Much of the knowledge of ocean circulation and mixing has been learned by following radioactive tracers injected into the environment during atmospheric nuclear weapons testing in the 1950 's. Short-term surface mixing in the Black Sea is poorly understood and the disaster at the Chernobyl nuclear power plant provided an opportunity to conduct a basin-wide mixing experiment.

The release of massive quantities of radionuclides to the lower atmosphere from the Chernobyl nuclear power station accident on 26 April 1986 has environmental radioecological implications which will extend far into the future. Initial studies showed that the Baltic Sea, being heavily impacted, is one area where fallout was high enough to be used to conduct an extensive range of experiments. The Black Sea, Norwegian/Greenland/Barents Seas and Arctic Ocean have subsequently been shown to have received substantial amounts of Chernobyl fallout. In addition to direct fallout, the Arctic Ocean can be expected to receive an advective input from the south as Atlantic water flows into it. Likewise, the Norwegian Sea will receive water exported from the Baltic Sea outflow. The Black Sea receives large amounts of river input in the northwest - mostly from the Danube and Dnieper Rivers. Both these rivers drain watersheds heavily impacted by Chernobyl fallout - the latter including the freshwater environment directly around the Chernobyl site itself.

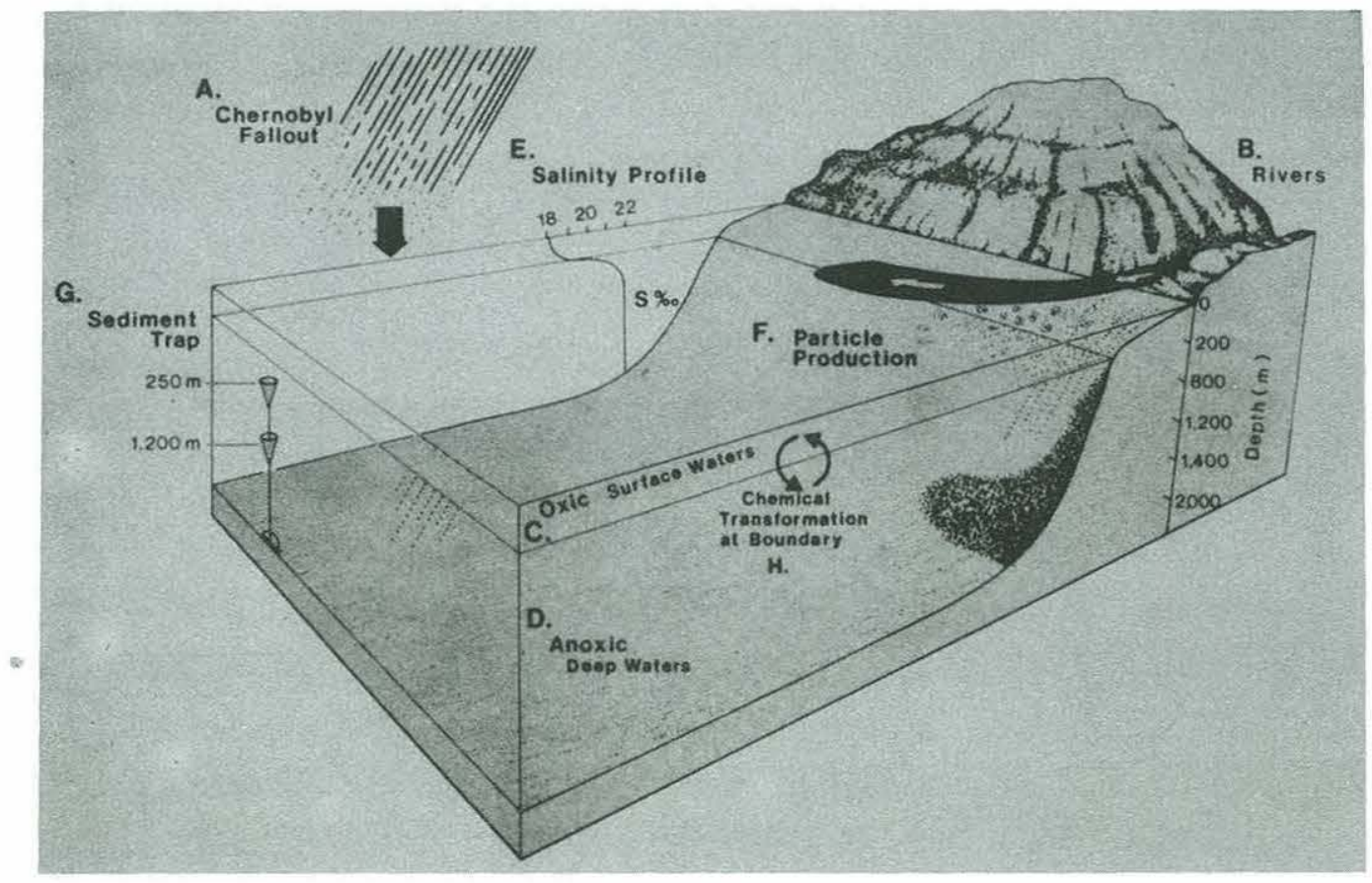


Using funding from CRC, Dr. H.D. Livingston's laboratory at the Woods Hole Oceanographic Institution collected samples in 1986, that were used to assess the geographical impact of Chernobyl fallout in the areas noted above. This information provided an assessment of possible radio-tracer experiments and established a partial base against which temporal changes have been noted. The suite of samples collected in June 1986 with CRC support provided information which showed that many new tracer studies could be undertaken in the Black Sea using the Chernobyl radioactivity. Since that time, Dr. Ken O. Buesseler joined with Dr. Livingston in pursuing these studies. ONR funding was obtained to analyze the summer 1986 samples and a two-year NSF grant supported further sampling and analyses, including participation in the multi-leg cruise in the Black Sea in summer 1988 on R/V Knorr. Several publications have resulted, others are in preparation, and a proposal for a further two years of NSF support for continued studies is pending. Future work includes participation with Soviet scientists on a Soviet ship on a cruise to the northwestern Black Sea in spring 1989.

\section{B . Massachusetts whale mortality}

During six weeks at the end of 1987, 14 dead humpback whales washed ashore along the beaches of Cape Cod Bay. Group mortality of this kind, while not unusual for toothed whales that are known to "mass strand" while still alive, is unprecedented for baleen whales. The nature and timing of the episode, behavioral observations of a terminally-ill animal, and the condition of the carcasses, convinced pathologists that a toxin was involved. Dr. D.M. Anderson of the WHOI Biology Department was invited to joint the investigating team to determine whether a toxin originating in the plankton was the cause of death. The most likely candidate was saxitoxin (STX), a potent neurotoxin produced by single-celled marine algae. This toxin is best known for its association with paralytic shellfish poisoning (PSP), which occurs when humans eat shellfish that have filtered the algae from the water as food and accumulated the toxin to dangerous levels. If the humpback whales were exposed to saxitoxin, it had to be through their food - typically the sand lance, but in 1987, the more abundant mackerel. Samples of freshly-caught mackerel as well as the stomach contents and tissues of the whales were analyzed. The mackerel tested positive for saxitoxin, but only in their viscera; muscle tissue was completely non-toxic. The whale tissues also showed evidence of the presence of a saxitoxin-like compound, thought to be a conversion product of the parent saxitoxin.

One fascinating aspect of this investigation relates to the question "How much toxin does it take to kill a 50,000 pound whale?" Based on the number of fish that such a whale can consume in one day (2000 mackerel, one pound each) and the average body burden of toxin in a mackerel, it was possible to estimate the dose that the whales received. The value obtained (normalized to body weight) was at the low end of the range known to have killed humans. Confounding factors that 
must be considered are that: a) much of the whale body is blubber, which should be discounted from the body weight calculations; b) the toxin would only have had to incapacitate the whales to slightly cause death by drowning; and c) the mammalian diving reflex would have cut off blood supply to peripheral tissues and concentrated the delivery of toxin to the brain, heart, and lungs during each dive. It will probably never be possible to prove conclusively that saxitoxin killed the whales, but the evidence points in that direction.

A major feature of this study is the discovery of STX in mackerel. Apart from its obvious implications to whales, humans, and other fish consumers, the finding challenges our fundamental understanding of the dynamics of saxitoxin in fish, since the levels in the mackerel were above those known to kill other fish species. The source of the toxin, the manner in which the mackerel accumulated the toxin without dying, and the general prevalence of this phenomenon in other important fishes, are all topics requiring future research. One result of this specific investigation is that investigators are now looking for other marine algal toxins as potential causes of marine mammal mortalities, a possibility that was never seriously considered before. In fact, the death of over 700 bottlenose dolphins along the coast between New Jersey and Florida is now being linked to a toxin originating in algae associated with recurrent red tides in Florida. CRC funds, through its Rapid Response Program, made it possible for Dr. Anderson to commit time and resources to the unexpected mortalities in Cape Cod Bay and to make this important contribution to our knowledge of the far-reaching effects of the toxins from marine phytoplankton.

\section{Georges Bank Book}

The period covered by this report saw the completion and publication of the book and atlas, Georges Bank, R.H. Backus (ed.), MIT Press, 1987. All associated with the development of this major review collectively breathed a sigh of relief when Georges Bank was finally published as few could forsee the energy, effort and expense that would be required when the project began. This significant contribution to regional science and policy is a model for future studies because of the thoroughness of its coverage and documentation.

One of the reviewers, John Imbrie, Doherty Professor of Oceanography at Brown University, lauded the effort:

"This extraordinary book gives an authoritative summary of what is know about the physics and biology of Georges Bank, and provides the background necessary for a rational consideration of related public policy issues. It also sets a new standard for multidisciplinary programs."

In 1979, the controversy around conflicting demands of petroleum production and fisheries led to the conclusion in Woods Hole that a synthesis of scientific information was needed in order to temper the heated oil vs. fish dispute. Scientists had been making basic oceanographic 
measurements on Georges Bank since the beginning of the $20^{\text {th }}$ century; since 1930 , government fishery scientists have worked there in an attempt to understand fluctuations in fish populations. Interest in offshore oil development prompted intensified chemical, geologic, physical and biologic studies on the Bank. The need for a synthesis of this disparate information was obvious to many, and one of CRC's first projects was created to meet that need.

Building on the results of three informal workshops (WHOI, 1977; Dalhousie University, 1979; University of New Hampshire, 1981) the editorial board for the book organized a series of day-long meetings in 1982 to exchange information and to organize the writing tasks. The goal was to review and synthesize all aspects of the natural science of the Bank, describe its rich resources, and explore public policy issues generated by the exploitation of these resources. The result is Georges Bank.

The ambitious goal of the book's planners was not only to synthesize all aspects of natural science of the bank and to consider public policy implications surrounding the exploitation of its rich resources. They also hoped to foster cross-disciplinary connections that would lead to wellconsidered interdisciplinary investigations on the Bank. These connections were made so well that new information about Georges Bank appears in print here for the first time and strengthens the review aspect of this volume. We anticipate that our effort will become an essential ingredient in rational policy decisions leading to the allocation of bank resources, and will be used as a base from which we take the next scientific steps leading to a greater understanding of the natural processes that produce the Bank's valuable resources.

\section{CRC STUDENT SUPPORT}

In order to maintain the coastal programs at WHOI, we support students and post-doctoral investigators at the institution. Student research programs have been satisfying and successful in the past. We solicit modest student proposals to fund research on coastal issues. The money is intended as seed money to help the student develop a thesis project, which, when fully developed, is funded through other channels. The student funds help innovative projects get off the ground by providing instrumentation, supplies, ship time and travel that are essential before a thesis project can be formulated. In the past we have successfully initiated research projects that have blossomed into research projects sponsored by federal agencies and private foundations. A list of pre-doctoral students who have received CRC support is found in Table 1.

Post-doctoral scholars have always been a strong mechanism for recruiting new scientists to WHOI. The Institution presently has a limited ability to fund post-doctoral scholars, usually providing one per department per year. With this limit, the potential for bringing in coastal specialists remains low. Consequently, the CRC has funded post-doctoral positions to try to 
maintain a balanced interest across all departments in the coastal zone. We hope to continue funding to increase these educational opportunities which serve to solidify interest in the coastal zone within the institution. A list of CRC-supported post-doctoral scholars is found in Table 2.

\section{TABLE 1.}

\section{CRC Pre-Doctoral Awards}

\section{Brian Binder}

Department/Advisor: Department of Biology/D. Anderson

Degree/Date: Ph.D./February, 1986

Dissertation Title: The Physiology of Dormancy and Germination in Cysts of the Marine Dinoflagellate Scrippsiella trochoidea.

\section{Bruce Brownawell}

Department/Advisor: Department of Chemistry/J. Farrington

Degree/Date: Ph.D./June 1986

DissertationTitle: The Role of Colloidal Organic Matter in the Biogeochemistry of PCBs in a Coastal Environment

Carol E. Diebel

Department/Advisor:

Degree/Date:

Department of Biology/L. Madin

Ph.D./June 1988

DissertationTitle: The Sensory Mediation of Symbiosis Between Hytperiid Amphipods and salps

\section{Dean M. Jacobson}

Department/Advisor:

Degree/Date:

Department of Biology/D. Anderson

Ph.D./February 1987

DissertationTitle: Feeding Mechanisms and Predation in Coastal and Oceanic Heterotrophic Dinoflagellate Populations

Melissa M. Lakich Department/Advisor:

Degree/Date:

Thesis Title:

\section{Department of Biology/C. Taylor}

M.Sc./June 1987

Mechanisms of Chlorophyll Diagenesis in Coastal Marine Sediments

John P. Jasper

Department/Advisor:

Degree/Date:

Department of Chemistry/R. Gagosian

Ph.D./June 1988

DissertationTitle: An Organic Geochemical Approach to Problems of GlacialInterglacial Climate Variability

Jill V. Scharold

Department/Advisor:

Degree/Date:

Department of Biology/J. McDowell

Ph.D./December 1988

DissertationTitle: Swimming Behavior and Energetics of Sharks 
TABLE 1. (continued)

Richard P. Signell

Department/Advisor: Department of Physical Oceanography

Degree/Date: $\quad$ M.Sc./January 1987

Thesis Title: $\quad$ Tide- and Wind-Forced Currents in Buzzards Bay, Massachusetts

Degree/Date: $\quad$ Ph.D./expected June 1989

Dissertation Title: Tidal Dynamics and Dispersion Around a Coastal Headland

\section{TABLE 2.}

\section{CRC Post-Doctoral_Awards}

Hans C. Graber

Sc.D.:

Now At:

Civil Engineering, Massachusetts Institute of Technology

Department of Ocean Engineering, Woods Hole Oceanographic Institution, Woods Hole, MA

Dr. Graber analyzed wave data during the CODE experiment and developed a marine surface wind model. He also used wind and wave data in the Yellow Sea to study their effects on wave-current interaction and sediment transport.

Mark Altabet

Ph.D.:

Now At:

Ocean Nitrogen Cycle, Harvard University

Department of Chemistry, Woods Hole Oceanographic Institution, Woods Hole, MA

Dr. Altabet has studied the biogeochemistry of nitrogen in coastal and open ocean areas, building on his thesis work of tracing warm-core rings in the Gulf Stream using nitrogen isotopes.

James B. Riley

Ph.D.:

Ocean Engineering, WHOI/MIT Joint Program

Now At:

MIT Lincoln Labs, Cambridge, MA

While associated with Dr. Yogi Agrawal, J. Riley worked on the development of instrumentation for particle sizing by laser diffraction in support of sediment transport studies. 


\section{VISITORS}

\section{Seminars, Visitors, Appointments}

One of the strengths of the Coastal Research Center has been its ability to support visitors to the Woods Hole Oceanographic community. CRC visitors bring new skills and new insights to the ongoing research effort and help us to foster multidisciplinary interactions that might not occur otherwise. Some of these visitors remain in Woods Hole for extended periods such as a sabbatical leave from their own institution (Guest Appointments); others are invited specifically to give a scientific talk (CRC Seminars). The Coastal Research Center staff and associated scientists also host individuals and groups who visit CRC and the Woods Hole scientific community. These visitors serve to broaden the scientific and funding base of CRC and often help to translate scientific results into useful information for policy makers and resource managers. The visitors to CRC during the period of this report are listed in Tables 3, 4, and 5 .

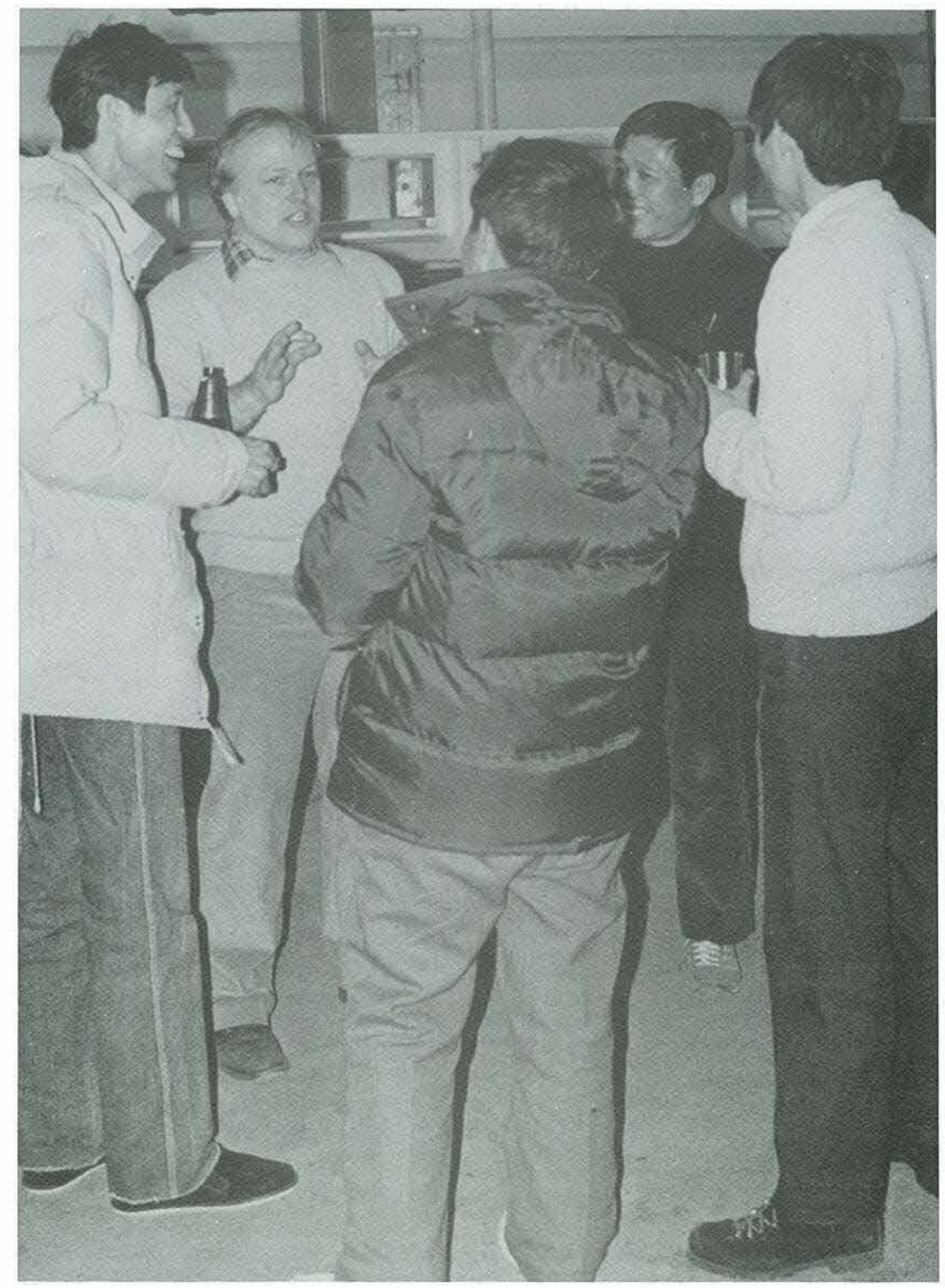


TABLE 3.

\section{CRC Guest Appointments}

John H. Gentile

U.S. EPA, Narragansett, Rhode Island

September 1987 - August 1989

WHOI Sponsor: J. McDowell, Biology

Donald C. Rhoads

Department of Geology

Yale University

September 1986 - July 1988

WHOI Sponsor: J. Farrington, Chemistry

D. Ross, Geology and Geophysics

\section{Douglas Lipka}

U.S. EPA, Narragansett, Rhode Island

September 1986 - August 1988

WHOI Sponsor: J. McDowell, Biology

\section{David Dyrssen}

Göteburg, Sweden

December 1986 - June 1987

WHOI Sponsor: P. Brewer, Chemistry

Drew Carey

Earth and Environmental Sciences

Wesleyan University

September 1985 - August 1987

WHOI Sponsor: J. Farrington, Chemistry

Hanuman Singh

Manipur University

Implel, India

June 1987 - August 1987

WHOI Sponsor: J. Stegeman, Biology 


\section{TABLE 4.}

\section{CRC Sponsored Seminars}

Dr. Des Connel

School of Australian Environmental Studies

Griffiths University

Queensland, Australia

Date: 25 March 1987

Title of Talk: "Lipophilic Toxicants in the Marine Environment"

Dr. Jan Boon

Ministry of Transport and Public Works

The Netherlands

Date: 22-24 April 1987

(attended $4^{\text {th }}$ International Symposium on Responses of Marine Organisms to Pollutants)

Title of Talk: "PCBs in Marine Mammals of the North Sea Coast: Chemistry and Biological Effects"

Dr. Robert Kirby

Ravensrodd Consultants Ltd.

Taunton, Somerset, U.K.

Date: 18 March 1988

Title of Talk: "Discontinuities in Estuarine Suspended Sediment Distribution Revealed by Continuous Profiling"

Dr. Bruce Hayden

Department of Environmental Sciences

University of Virginia

Date: 6 July 1988

Title of Talk: "Coastal Storms and Climate Change" 


\section{TABLE 5.}

\section{WHOU/CRC Visitors}

Charles A. Dana III

Hoan Su You
WHOI Corporation Member

Chonnam National University

Republic of Korea

Yong Ahn Park, Soochal Park

Luigi Zanda

Ms. Pierette Lucas

Ms. Catherine O'Riorden

L. Jeftic

Staff engineers

Sec. James S. Hoyte

Richard Delaney
Seoul National University

Seoul, Korea

Venice, Italy

Canadian Consul General, with

Canadian Senate Committee on Fisheries

Massachusetts DEQE,

Division of Water Pollution Control, with Technical Services Branch staff.

United Nations Environment Programme/

Athens, Greece

Netherlands Institute of Sea Research

Massachusetts Executive Office of

Environmental Affairs, with

Director, Massachusetts Office of

Coastal Zone Management
June 1987

August 1987

February 1988

March 1988

March 1988

April 1988

April 1988

April 1988

June 1988

\section{B. H. Ketchum Award}

Buck Ketchum was a major figure in oceanographic research and as a scientific leader in Woods Hole, his pioneering research provided the basis for our present understanding of the productivity of the oceans. In his later years he turned his attention to the increasing problems of the coastal zone and the need for research in this area. He was an outstanding scientist at the international level, a strong force in the development of oceanography in Woods Hole, and a respected member of the community.

Each year the Woods Hole Oceanographic Institution sponsors one or two lectures which bring an internationally-recognized oceanographer to Woods Hole or brings young scientists here for a longer visit. This lecture series is named in honor of the late Bostwick H. Ketchum. The Coastal Research Center administers the Ketchum Award. 


\section{B.H. Ketchum Award Recipients}

1987: John S. Allen

College of Oceanography

Oregon State University

Corvallis, OR

Award Lecture: "Large Scale Dynamics of the Coastal Ocean"

1988: Alasdair D. McIntyre

Marine Laboratory

University of Aberdeen

Aberdeen, Scotland

Award Lecture: "The Health of the Oceans"

\section{CRC SYMPOSIA, WORKSHOPS}

The Coastal Research Center often provides partial support in the form of travel, publication or organizational expenses for symposia and workshops in Woods Hole or elsewhere. These scientific meetings have successfully brought scientists together to discuss topics of scientific interest that have immediate societal implications. During the period of this report, two such meetings were supported with $\mathrm{CRC}$ funds. The are summarized briefly here.

\section{Hydrodynamics and Sediment Dynamics of Tidal Inlets An International Symposium \\ Woods Hole, December 1986}

\section{Joint Sponsors: $\quad$ WHOI Sea Grant U.S. Army Corps of Engineers \\ WHOI Covener: David G. Aubrey}

The research papers presented at the tidal inlet symposium were compiled and published in Springer-Verlag "Lecture Notes on Coastal and Estuarine Studies" series: "Hydrodynamics and Sediment Dynamics of Tidal Inlets", D.G. Aubrey and Lee Weishar (eds.). Tidal inlets provide a link between embayments and the coastal ocean, exchanging water, sediments, nutrients, planktonic organisms and pollutants between them. The symposium volume provides a broad overview of modern tidal inlet research and focuses on major research questions currently facing the scientific community in this area. 
$4^{\text {th }}$ International Symposium on Responses of Marine Organisms to Pollutants Woods Hole, April 1987

\author{
Joint Sponsors: Institute for Marine Environmental Research \\ Plymouth, England \\ WHOI Covener: John J. Stegeman
}

The Fourth International Symposium on Responses of Marine Organisms to Pollutants was held 22-24 April 1987 at Woods Hole Oceanographic Institution. The symposium dealt with mechanisms and processes involved in pollutant biotransformation, detoxification, and toxicity. Topics such as biochemistry of metal binding proteins, biochemistry of cytochrome P-450 and biotransformation enzymes, mechanistic responses involving critical processes of reproduction, development and defense, and toxicological consequences involving oxidative damage were emphasized, but immunological and molecular biological approaches were considered in a special session. The proceedings of this symposium was published as a special issue of the journal Marine Environmental Research, (vol. 24, No. 1-4, 1988).

\title{
CRC FACULUTUES
}

\section{CoastaL_Research Laboratory}

The Coastal Research Laboratory, constructed in 1981-1982 and expanded in 1984, serves the needs of several scientific programs of the Institution with a mix of flexible experimental space and offices and permanently assigned laboratories. A large test tank for testing small, remotely piloted vehicles has been installed in the Experimental Bay area and is utilized periodically by the WHOI Deep Submergence Laboratory group and others. Dr. Jack Whitehead's Geophysical Fluid Dynamics Laboratory, equipped with a 2-meter rotating table and ancillary equipment, is used for a variety of research experiments by Dr. Whitehead and his colleagues at WHOI, and attracts visitors from other research organizations for joint experiments. Dr. Judy McDowell Capuzzo's research laboratories and two temperature controlled culture laboratories are fully occupied with a variety of research efforts concerned with biochemistry, nutrition, physiology, reproduction, effects of natural and pollution-related stress on marine organisms, and aquaculture. The Physical Measurements Laboratory is home to some types of instrument development (such as the Laser Doppler Velocity Meter) and flume-related research.

A Machine Shop operated by Coastal Research Laboratory participants is the only such facility on the Quissett Campus of WHOI. Hand tools and standard machine tools (e.g., lathe, drill press, grinder, etc.) are available for use by the staff. 
Experimental Bay Space has been allocated for a variety of purposes over the past years:

1) In-situ pump systems for oceanic geochemical studies have been maintained and modified between cruises.

2) Modification, maintenance, and instrument calibration for the portable laboratory van (for measurements of $\mathrm{CO}_{2}$ and related parameters at sea).

3) Refurbishment and preparation of in-situ pumps for organic geochemistry studies.

4) Maintenance of WHOI small boats.

5) Preparation prior to deployment in the equatorial Atlantic of SOFAR instrumentation. The CRC test tank was used to measure precisely the weight of each instrument in order to ballast the float to be neutrally buoyant at a specific depth.

In addition, numerous small, short-term experiments have been conducted in the High Bay area and several large vans or sea-going sampling and measurement devices have been housed for short-term refurbishment prior to going to sea or returning to storage elsewhere.

To complement the laboratory space, six offices are maintained at CRL for use of visitors or WHOI staff participating in CRC projects or utilizing the Experimental Bay space.

\section{Elume Instrumentation}

A major CRC effort has become a reality with two pieces of instrumentation now being operational in the Coastal Research Laboratory Experimental Bay area.

The larger instrument is the 17 -meter long flume designed by the late Dr. William D. Grant and co-workers to perform basic research on animal-sediment interactions at the benthic boundary. The steady water flow is gravity-driven by tilting the entire raceway on hydraulic jack; an adjustable vertical wier downstream allows maintenance of a constant water depth all along the raceway for each flow speed. This flume is designed primarily for sediment-transport and animalsediment interaction experiments, and operates best at relatively high pumping rates. The flume is equipped with a 2-axis, forward-scatter Laser Doppler Velocimeter designed and constructed by Dr. Yogesh Agrawal, formerly of the WHOI Ocean Engineering Department. This LDV is used to measure the horizontal and vertical velocity components at any location along the 17-meter raceway. The LDV data can be acquired and roughly plotted using a NEC personal computer located next to the flume; detailed processing of the LDV data is completed on the WHOI VAX. The flume has a 2-cm thick removable false bottom all along the raceway to allow current profiling down to the bed. Any section can be removed and replaced with sediments to the level of $2 \mathrm{~cm}$ for experiments or, alternatively, a $53-\mathrm{cm}$ by $53-\mathrm{cm}$ by $30-\mathrm{cm}$ deep box can be inserted into the flume bottom approximately $15-\mathrm{m}$ from the flow entrance to allow experiments with thicker sediments and deeper-dwelling organisms. A water-cooling unit installed in the flume can cool $25^{\circ} \mathrm{C}$ water down to a minimum of $4^{\circ} \mathrm{C}$ in about a day and maintain the desired water temperature to $\pm 1^{\circ} \mathrm{C}$. 

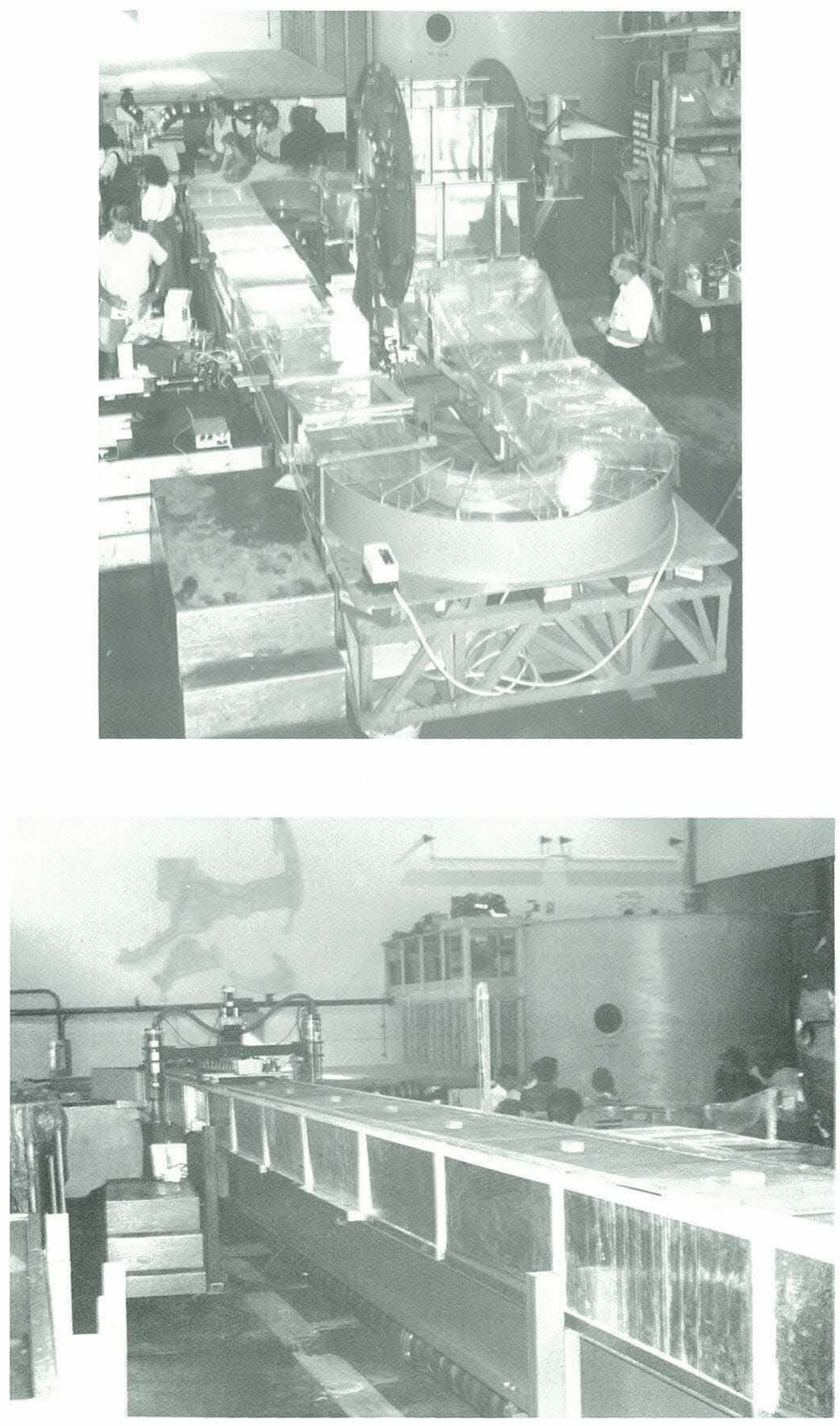

Two operational flumes at the Coastal Research Laboratory. Upper photo depicts the Race Track Flume. 17-Meter Flume designed by Bill Grant and co-workers is shown in the lower photo. 
The flume can be filled with fresh 5-micron filtered seawater or with freshwater as needed. The cooling system allows experiments to be conducted on local fauna which require cool water as a part of their life cycle. This flume is unique in its mix of precise flow control, boundary layer measurement tools, and design for study of sediment-animal interactions.

In addition to the 17-meter flume, the Coastal Research Center recently acquired a racetrack flume from Drs. Donald Rhoads and Larry Boyer of Yale University. This flume has a racetrack about $6-\mathrm{m}$ long, $50-\mathrm{cm}$ wide and $30-\mathrm{cm}$ deep. The water flow is driven by a paddle wheel making the racetrack flume an excellent research tool for experiments where organisms (e.g., planktonic larvae) or delicate sediment flocs are recirculated. Lower flow speeds are anticipated in comparison to the $20-\mathrm{m}$ flume and gentle recirculation will permit study of sediment floc or organisms with minimal impact on morphology or behavior. This flume also has a false bottom, like the 20-meter flume, which allows sediment depths up to $10 \mathrm{~cm}$ along the test-section straightway.

Since the flumes were constructed in 1986, they have been used by investigators representing different fields including benthic ecology, sediment transport, fluid mechanics and bottom turbulence. The facility has spawned numerous scientific articles. The interdisciplinary flavor of the flume facility, plus the precision with which hydrodynamic questions can be addressed and answered, make it appropriate that they are dedicated to the memory of Dr. William Grant, our colleague and friend, who provided the energy and wisdom to initiate this work and the persistence to see it carried to a successful conclusion.

These flumes are a CRC-facility and are available for use by coastal researchers. To support essential maintenance and calibration, a user fee will be assessed. To schedule time on the flume, contact CRC Director Dr. David Aubrey or CRC Coordinator Mr. Bruce Tripp.

\section{Small boat fleet}

CRC maintains a fleet of small boats for the use of coastal researchers. This fleet includes:

$8 \mathrm{ft.}$ Aluminum Skiff

$11 \mathrm{ft}$. Inflatable boat

$13 \mathrm{ft}$. Boston Whaler

$17 \mathrm{ft}$. Boston Whaler

$19 \mathrm{ft}$. Boston Whaler

$20 \mathrm{ft}$. Bertram inboard/outboard

$22 \mathrm{ft}$. Catamaran (flat top, outboard engines)

After training in small boat handling, CRC investigators may borrow any of these craft for their own research. The small boats are maintained in a sea-worthy condition, with essential safety 
and communication equipment, at little or no cost to individual projects. To schedule time with the boat fleet, contact Mr. Wayne Spencer.

\title{
4. Miscellaneous equipment
}

CRC maintains other equipment and instrumentation that is available for loan to investigators in some cases. Available equipment includes:

\author{
Oscilloscope \\ Multimeter \\ Lamda voltage power supply \\ $3 \mathrm{KW}$ Honda electrical generator \\ 1.5 KW Honda electrical generator \\ Gould 4-channel strip chart recorder \\ Hewlett-Packard 6 pin plotter \\ 2 in. trash pump \\ 3 in. trash pump \\ $\mathrm{X}$-ray machine \\ $200 \mathrm{kHz}$ fathometer
}




\section{APPENDICES}

\section{CRC Publications}

Agrawal, Y.C., F. Dias and D.G. Aubrey, submitted. Field observations of the coastal bottom boundary layer under surface gravity waves.

Anderson, D.M., A.W. White and D.G. Baden (eds.), 1985. Toxic Dinoflagellates, Elsevier, New York, 561 pp.

Aubrey, D.G., 1983. Beach changes on coasts with different wave climates. In: Sandy Beaches as Ecosystems, McLachlan, A. and T. Erasmus (eds.), D.W. Junk Publishers, The Hague, p. 63-85.

Aubrey, D.G. and P.E. Speer, 1985. A study of non-linear tidal propagation in shallow inlet/estuarine systems. Part I: Observations. Estuarine, Coastal and Shelf Science, 21: $185-205$.

Aubrey, D.G. 1985. Recent sea levels from tide gauges: problems and prognosis. In: Glaciers, ice sheets and sea level: effects of a $\mathrm{CO}_{2}$-induced climatic change, Meier, M. (ed.), National Academy of Science Press, Washington, D.C., p. 73-91.

Aubrey, D.G. and R.M. Ross, 1985. Quantitative description of beach cycles. Marine Geology, 69: $155-170$.

Aubrey, D.G. and K.O. Emery, 1986. Relative sea levels of Japan from tide-gauge records. Geol. Soc. America Bull., 97: 194-205.

Aubrey, D.G., 1986. Hydrodynamic controls on sediment transport in well-mixed bays and estuaries. In: Physics of Shallow Estuaries and Bays, van de Kreeke, J. (ed.), SpringerVerlag, p. 245-258.

Aubrey, D.G. and K.O. Emery, 1986. Australia - an unstable platform for tide-gauge measurements of changing sea levels. Journal of Geology, 94: 699-712.

Aubrey, D.G. and K.O. Emery, 1986. Relative sea levels of Japan from tide-gauge records: Discussion and reply. Bulletin of the Geological Society of America, 97: 1281-1282.

Aubrey, D.G. and C.T. Friedrichs, 1988. Seasonal climatology of tidal non-linearities in a shallow estuary. In: Lecture Notes on Coastal and Estuarine Studies, Vol. 29, Aubrey, D.G. and Weishar, L. (eds.), Hydrodynamics and Sediment Dynamics of Tidal Inlets, Springer-Verlag, New York, p.103-124.

Aubrey, D.G., K.O. Emery and E. Uchupi, 1988. Changing coastal levels of South America and the Caribbean region from tide-gauge records. Tectonophysics, 154: 269-284.

Aubrey, D.G. and L. Weishar (eds.), 1988. Hydrodynamics and Sediment Dynamics of Tidal Inlets. In: Lecture Notes on Coastal and Estuarine Studies, Springer-Verlag, NY, 29, 456 pp.

Aubrey, D.G. and K.O. Emery, (submitted). Recent global sea levels and land levels. Proceedings Climate Change Workshop, Norwich, U.K.

Backus, R.H. (ed.), 1987. Georges Bank. MIT Press, Cambridge, MA, 593 pp.

Binder, B.J. and D.M. Anderson, 1986. Green light-mediated photomorphogenesis in a dinoflagellate resting cyst. Nature, 322: 659-661.

Binder, B.J. and D.M. Anderson, 1987. Physiological and environmental control of germination in Scrippsiella trochoidea (Dinophyceae) resting cysts. J. Phycol., 23: 99-107.

Braatz, B.V. and D.G. Aubrey, 1987. Recent relative sea-level change in eastern North America. In: Sea-Level Fluctuation and Coastal Evolution, Nummedal, D., O.H. Pilkey and J.D. Howard (eds.), Society of Economic Paleontologists and Mineralogists, Special Publication No. 41, p. 29-46.

Broadus, J.M., J.D. Milliman, S.F. Edwards, D.G. Aubrey and F. Gable, 1986. Rising sea level and damming of rivers: possible effects in Egypt and Bangladesh. In: Effects of Changes in Stratospheric Ozone and Global Climate, 4, Sea Level Rise, EPA/UNEP, p. 165-189. 
Buesseler, K.O., H.D. Livingston, S. Honjo, B.J. Hay, S.J. Manganini, E. Degens, V. Ittekkot, E. Izdar and T. Konuk, 1987. Chernobyl radionuclides in a Black Sea sediment trap. Nature, 329(6142):825-828.

Butman, C.A., 1986. Larval settlement of soft-sediment invertebrates: Some predictions based on an analysis of near-bottom velocity profiles. In: Marine Interfaces Ecohydrodynamics, Nihoul, J.C.J. (ed.), Elsevier Oceanography Series, 42, Elsevier, Amsterdam, p. 487514.

Butman, C.A., 1986. Sediment trap biases in turbulent flows: Results of a laboratory flume study. Journal of Marine Research, 44: 645-693.

Butman, C.A., W.D. Grant and K.D. Stolzenbach, 1986. Predictions of sediment trap biases in turbulent flows: A theoretical analysis based on observations from the literature. Journal of Marine Research, 44: 601-644.

Butman, C.A., 1987. Larval settlement of soft-sediment invertebrates: The spatial scales of pattern explained by active habitat selection and the emerging role of hydrodynamical processes. Oceanogr. Mar. Biol. Ann. Rev., 25: 113-165.

Butman, C.A., J.P. Grassle and E.J. Buskey, 1988. Horizontal swimming and gravitational sinking of Capitella Sp. I (Annelida: Polychaeta) larvae: Implications for settlement. Ophelia, 29: 43-57.

Butman, C.A., J.P. Grassle and C.M. Webb, 1988. Substrate choices made by marine larvae settling in still water and in a flume flow. Nature, 333: 771-773.

Butman, C.A., R.J. Chapman and W.R. Geyer, submitted. The 17-Meter Flume: Description, calibration and operating constraints. Woods Hole Oceanographic Institution Technical Report.

Carey, D.A. and P. Gruntmeyer, 1986. Faunal inventory and geomorphic survey of some sublittoral habitats of Griswold Point Preserve. Final Report to the Connecticut Chapter of the Nature Conservancy.

Carey, D.A. and J.W. Farrington, in press. Polycyclic aromatic hydrocarbons in Saccoglossus kowalewskyi (Agassiz), Estuarine, Coastal and Shelf Research.

Carey, D.A., submitted. Fluorometric detection of tracer particles used to study animal-particle dynamics. Limnology and Oceanography.

Chapman, D.C. and G.S. Giese, 1987. A model for the generation of coastal seiches by deep-sea internal waves. EOS, 68(50): 1720.

Chapman, D.C. and G.S. Giese, submitted. A model for the generation of coastal seiches by deep-sea internal waves. Journal of Physical Oceanography.

Chapman, R.J. and R.E. Galat, submitted. Cooling the waters of the 17-Meter Flume. Woods Hole Oceanographic Institution Technical Report.

Davis, C.S., 1987. Components of the zooplankton production cycle in the temperate ocean. Journal of Marine Research, 45: 947-983.

Emery, K.O. and D.G. Aubrey, 1986. Glacial rebound and relative sea levels in Europe from tide-gauge records. Tectonophysics, 120: 239-255.

Emery, K.O. and D.G. Aubrey, 1986. Relative sea-level changes from tide-gauge records of eastern Asia mainland. Marine Geology, 72: 33-45.

Emery, K.O. and D.G. Aubrey, 1986. Relative sea-level changes from tide-gauge records of western North America. Journal of Geophysical Research< 91: 13941-13953.

Emery, K.O., D.G. Aubrey and V. Goldsmith, 1988. Coastal neo-tectonics of the Mediterranean from tide-gauge records. Marine Geology, 81: 41-52.

Farrington, J.W., A.C. Davis, N.M. Frew and A. Knap, 1988. ICES/IOC Intercomparison Exercise on the Determination of Petroleum Hydrocarbons in Biological Tissues (Mussel homogenate). Marine Pollution Bulletin, 19(8):372-380.

Friedrichs, C.T. and D.G. Aubrey, in press. Impacts of rising sea levels on nonlinear circulation and sediment transport patterns in shallow, well-mixed embayments.

Fry, V.A. and D.G. Aubrey, in press. Tidal velocity asymmetries and bedload transport in shallow embayments. Estuarine, Coastal and Shelf Science, 
Fuller, C.M., C.A. Butman and N.M. Conway, 1988. Periodicity in fecal pellet production by the capitellid polychaete Mediomastus ambiseta throughout the day. Ophelia, 29, 83-91.

Geracci, J.R., D.M. Anderson, R.J. Timperi, G. Early and J.H. Prescott (submitted). Extraordinary whale mortality linked to saxitoxin discovered in mackerel (Seomber scombrus)

Giese, G.S., 1988. Introduction to Implication of Climatic Changes in the Wider Caribbean Region, a Report by a Task Team of Experts. United Nations Environment Programme Report: UNEP(OCA)/CAR WG1/INF.3, p. 23-26.

Giese, G.S., D.G. Aubrey and P. Zeeb, 1987. Passive retreat of Massachusetts coastal upland due to relative sea-level rise. Commonwealth of Massachusetts, Coastal Zone Management Office.

Giese, G.S. and D.G. Aubrey, 1987. Losing coastal upland to relative sea-level rise: 3 scenarios for Massachusetts. Oceanus, 30: 16-27.

Giese, G.S. and D.C. Chapman, 1987. Is the generation of coastal seiches by deep-sea internal waves a global phenomenon? EOS, 68(50):1720.

Giese, G.S., 1988. Cyclical behavior of the tidal inlet at Nauset Beach, Chatham, Massachusetts. In: Lecture Notes on Coastal and Estuarine Studies, Vol. 29, Aubrey, D.G. and Weishar, L. (eds.), Hydrodynamics and Sediment Dynamics of Tidal Inlets, Springer-Verlag, New York, p. 269-283

Grassle, J.P. and C.A. Butman, submitted. Active habitat selection by larvae of the polychaetes, Capitella ssp. I and II, in a laboratory flume. Proceedings of the $23^{\text {rd }}$ European Marine Biology Symposium, Ryland, J.S. and P.A. Tyler (eds.).

Howes, B.L., J.W.H. Dacey and D.D. Goehringer, 1986. Factors controlling the growth form of Spartina alteriflora: feedback between above-ground production, sediment oxidation, nitrogen and salinity. J. Ecol.,74:881-898.

Hannan, C.A., 1984. Planktonic larvae may act like passive particles in turbulent near-bottom flows. Limnology and Oceanography, 29: 1108-1116.

Jacobson, D.M. and D.M. Anderson, 1986. Thecate heterotrophic dinoflagellates: Feeding behavior and mechanisms. J. Phycol., 22: 249-258.

Kempe, S., H. Nies, V. Ittekkot, E.T. Degens, K.O. Buesseler, H.D. Livingston, S. Honjo, B.J. Hay, S.J. Manganini, E. Izdar and T. Konuk, 1987. Comparison of Chernobyl Nuclide Deposition in the Black Sea and in the North Sea. Mitt. Geol. Paläont. Inst., Univ. Hamburg, SCOPE/UNEP Sonderband, Heft 62, 165-178.

Lee, C., 1988. Amino acid and amine biogeochemistry in marine particulate material and sediments. In: Nitrogen Cycling in Coastal Marine Environments, Blackburn, T.H. and J. Sorensen (eds.), John Wiley \& Sons Ltd.

Libes, S.M. and W.G. Deuser, 1988. The isotope geochemistry of particulate nitrogen in the Peru Upwelling Area and the Gulf of Maine. Deep-sea Research, 35(4A): 517-533.

Livingston, H.D., K.O. Buesseler, E. Izdar and T. Konuk, in press. Characteristics of Chernobyl fallout in the Southern Black Sea. In: Radioactivity and Oceanography, Radionuclides: A Tool for Oceanography, Elsevier Applied Science.

Lohrenz, S.E. and C.D. Taylor, 1987. Inorganic ${ }^{14} \mathrm{C}$ as a probe of growth rate-dependent variations in intracellular free amino acid and protein composition of $\mathrm{NH}_{4}$-limited continuous cultures of Nannochloris atomis Butcher. J. Exp. Mar. Biol. Ecol., 106: 31-55.

Lohrenz, S.E. and C.D. Taylor, 1987. Primary production of protein: I. Comparison of net cellular carbon and protein synthesis with ${ }^{14} \mathrm{C}$-derived rate estimates in steady-state cultures of marine phytoplankton. Marine Ecology Progress Series, 35: 277-292.

Lohrenz, S.E., C.D. Taylor and B.L. Howes, 1987. Primary production of protein: II. Algal protein metabolism and its relation to particulate organic matter composition in the surface mixed layer. Marine Ecology Progress Series, 40: 175-183.

Meier, M.F., D.G. Aubrey, C.R. Bentley, W.S. Broecker, J.E. Hansen, W.R. Peltier and R.C.J. Somerville, 1985. Glaciers, Ice Sheets, and Sea Level: Effects of a $\mathrm{CO}_{2}$-Induced Climatic Change. National Academy of Science Press, Washington, D.C., 330 pp. 
Martin, W.R. and F.L. Sayles, 1987. Seasonal cycles of particle and solute transport processes in nearshore sediments: ${ }^{222} \mathrm{Rn} / 226 \mathrm{Ra}$ and ${ }^{234} \mathrm{Th} / 238 \mathrm{U}$ disequilibrium at a site in Buzzards Bay, MA. Geochimica et Cosmochimica Acta, 51: 927-943.

McNichol, A.P., C. Lee and E.R.M. Druffel, 1988. Carbon cycling in coastal sediments: 1. A quantitative estimate of the remineralization of organic carbon in the sediments of Buzzards Bay, MA, Geochimica et Cosmochimica Acta, 52: 1531-1543.

Mullineaux, L.S., C.A. Butman and C.M. Fuller, in press. Effects of boundary-layer flow on the settlement of organisms onto flat plates: Preliminary results from Cross Seamount. NOAA Symposium Series for Undersea Research 6(2).

Stegeman, J.J. and M.N. Moore (Guest Editors) 1988. Response of Marine Organisms to Pollutants. Special Issue. In: Marine Environmental Research, vol. 24, Roesijadi, G. and R.B. Spies (eds.), Elsevier Applied Science, 356 pp.

Selig, D.E., 1988. An investigation of panne maintenance by select edaphic conditions. Honors thesis, Wesleyan University.

Signell, R.P., 1987. Tide- and wind-forced currents in Buzzards Bay, Massachusetts. Woods Hole Oceanographic Institution Technical Report No. WHOI-87-15.

Speer, P.E. and D.G. Aubrey, 1985. A study of non-linear tidal propagation in shallow inlet/estuarine systems. Part II: Theory. Estuarine, Coastal and Shelf Science, 21: 207224.

Uchupi, E. and D.G. Aubrey, 1988. Autochthonous/allochthonous terraces in the North American margins and sea level from tide gauges. Journal of Geology, 96: 79-90.

Wakeham, S.G., B.L. Howes, J.W. Dacey, R.P. Schwarzenbach and J. Zeyer, 1987. Biogeochemistry of dimethylsulfide in a seasonally stratified coastal salt pond. Geochimica et Cosmochimica Acta, 51:1675-1684.

Wang, Y. and D.G. Aubrey, 1987. The characteristics of the China coast. Continental Shelf Research, 7: 329-349.

Webb, C.M., submitted. Larval swimming and substrate selection in the brittle star Ophioderma brevispinum. Proceedings of the $23^{\text {rd }}$ European Marine Biology Symposium, Ryland, J.S. and P.A. Tyler (eds.). 


\section{TABLE OF CONTENTS}

\section{A. GEORGES BANK}

R.H. BACKUS, Editor-in-Chief

D.W. Bourne, Associate Editor

Foreword

Chapter

1 Scientific Exploration

2 Cartographic History, 1524-1850

PHYSICAL SCIENCE

Geology

3 Morphology

4 Shallow Structure, Surficial Geology, and the Processes Currently Shaping the Book

5 Subsurface Geology

6 Submarine Canyons

Weather and Climate

7 Atmospheric Variables and Patterns

8 Wave Climate

9 Tides

Physical Oceanography

Death on Georges Bank

10 Hydrographic Structure and Variability

11 The Seasonal Mean Circulation: Observation and Theory

12 Low-Frequency Current and Bottom-Pressure Variability

13 Physical Processes Causing Surficial Sediment Movement

14 Mixing Processes

15 Dissolved Gases

16 Trace Metals

17 Natural Radionuclides

18 Artificial Radionuclides

19 Natural and Pollutant Organic Compounds

\section{BIOLOGY}

Phytoplankton, Primary Production, and Microbiology

20 Phytoplankton

21 Primary Production

22 Nitrogen Cycling on Georges Bank and the New York Shelf: A Comparison between Well-Mixed and Seasonally Stratified Waters

23 Microbiology

Zoology and Secondary Production

24 Zooplankton Life Cycles

25 Zooplankton Production and the Fisheries of the Northeastern Shelf

26 Benthic Fauna
Cambridge, MA; London, England
The MIT Press 
Chapter

27 Variability of the Benthic Fauna, I. The New England Outer Continental Shelf Environmental Benchmark Program

28 Variability of the Benthic Fauna, II. The Seasonal Variation, 1981-1982

29 Production by the Benthic Fauna

30 Fishes and Squids

31 Fish and Squid Production

32 Large Pelagic Predators

33 Sea Turtles

34 Seabirds

35 Energy Transfer to Seabirds

36 Whales, Dolphins, and Porpoises

37 Production on Georges Bank Compared with Other Shelf Ecosystems

38 Some Biologic Implications of the Circulation

39 A Simulation of Some Physical and Biologic Interactions

THE FISHERIES

The Fisheries

40 History of the Early Fisheries

"Bait Up!": Dory Fishing on Georges Bank

Some Georges Bank Fishing Vessels

41 History of Fisheries Conservation and Management

42 Fishing Vessels and Gear in New England Waters: 1930-1983

My First Trip on Georges Bank

43 A Social and Economic View of the New England Offshore Fishing Industry

44 The Canadian Fishing Industry and Georges Bank

45 The Georges Bank/Gulf of Maine Boundary Dispute Between the United States and Canada

46 Fisheries Administration and Management in Canada and the United States: Implications for Georges Bank

47 The Fisheries Resources

48 Fish Population Dynamics

49 The Future for Fisheries Management on Georges Bank: An Opinion

An Echo-Sounder Record from the Northern Edge

CONFLICTING USES

Conflicting Uses

50 The Petroleum Potential of Georges Bank Basin

51 The Jurisdictional Framework for Petroleum Development

52 The Potential Effects of Drilling Effluents on Marine Organisms on Georges Bank

53 The Potential Effects of Petroleum on Marine Organisms on Georges Bank

54 Environmental-Protection Programs for Developing Georges Bank Petroleum Reserves

55 The Politics of Oil Drilling on Georges Bank: A State's Perspective

56 Exploratory Drilling, 1981-1982

57 Marine Surface Traffic

Afterword

Authors and Reviewers

Index 
B HYDRODYNAMICS AND SEDIMENT DYNAMICS OF TIDAL INLETS

$\begin{array}{ll}\text { D.G. Aubrey and L. Weishar, Editors } & \text { Lecture Notes on Coastal and Estuarine Studies, } \\ \text { Springer-Verlag, New York }\end{array}$

Preface

Chapter

MATHEMATICAL MODELING OF TIDAL INLET HYDRODYNAMICS

Hydrodynamics of Tidal Inlets

The Overtide and Filtering Response of Small Inlet/Bay Systems

Development and Application of Coastal and Inlet Processes Modeling System

Effects of Man-Made Channels on Estuaries: An Example, Apalachicola Bay, Florida

Port of Miami Inlet Dynamics

II OBSERVATIONS OF TIDAL INLET HYDRODYNAMICS

Seasonal Climatology of Tidal Non-Linearities in a Shallow Estuary.

Temporal Variation of Shallow-Water Tides in Basin-Inlet Systems

Small-Scale Inlets as Tidal Filters

Enhancement of Semidiurnal Tidal Currents in the Tidal Inlets to

Mississippi Sound

DARTS (Digital Automated Radar Tracking System) Application to Tidal Inlet

Hydrodynamic Studies

III SEDIMENT DYNAMICS AND MORPHOLOGY OF TIDAL INLETS

Shoreline Erosional-Depositional Processes Associated with Tidal Inlets

Stability of Tidal Inlet Navigation Channels and Adjacent Dredge Spoil Islands

Observations of Suspended Sediment Flux Over a Tidal Cycle in the Region of the

Turbidity Maximum of the Upper St. Lawrence River Estuary

An Ephemeral Inlet from the Virginia Barrier Island Chain: Stratigraphic Sequence and Preservational Potential of Infilled Sediments

Cyclical Behavior of the Tidal Inlet at Nauset Beach, Chatham, Massachusetts

IV SEDIMENT DYNAMICS AND MORPHOLOGY OF TIDAL DELTAS

Sediment Trapping at Florida's East Coast Inlets

Processes of Sediment Exchange Between Tidal Inlets, Ebb Deltas and Barrier Islands

Inlet Flood Tidal Delta Development Through Sediment Transport Processes

Ebb-Tidal Delta Dynamics for a Tide-Dominated Barrier Island

Ebb-Tidal Delta Response to Jetty Construction at Three South Carolina Inlets

Evolution of an Ebb-Tidal Delta After an Inlet Relocation

V MANAGEMENT/POLICY

Sediment Interaction at Modified Coastal Inlets: Processes and Policies

Effects of Shore Protection and Dredging Projects on Beach Configuration Near Unjettied

Tidal Inlets in New Jersey 
C. THE FOURTH INTERNATIONAL SYMPOSIUM ON RESPONSES OF MARINE ORGANISMS TO POLLUTANTS

J.J. Stegeman and M.N. Moore (Guest Editors)

Marine Environmental Research

Special Issue, Elsevier Applied Science

Editorial

Session Chairs

SECTION

1 CYTOCHROME P-450 AND BIOTRANSFORMATION

Monooxygenases in Mammals and Birds

Induction and Localization

Influence of Diet

Uptake, Metabolism and Disposition

Conjugating Enzymes

2 METALS AND METAL-BINDING PROTEINS

Uptake of Metals

Metallothionein and Binding Proteins

3

BIOCHEMICAL AND PHYSIOLOGICAL CHANGES

Reproduction and Growth

Biochemical Changes

Hematological Measures

Multivariate Analysis and Field Studies

4 PATHOBIOLOGY

Cellular and Organ Effects

Oxidative Damage

Neoplastic disease

DNÄ Damage

Molecular Biology 


\section{CRC RESEARCH AWARDS}

\section{Department}

Ocean Engineering

Chemistry

Chemistry

Chemistry

Biology

Biology

Biology

Biology

Biology/Chemistry
Investigator

Y.C. Agrawal

H.D. Livingston

C. Lee

E.R. Sholkovitz

D.M. Anderson

C. Davis

J.M. Teal

J. Stegeman

J. M. Capuzzo/

J. W. Farrington

\section{Purpose}

Travel funds, attend conference, Applications of Laser Velocimetry to Fluid Mechanics, Lisbon, Portugal.

Cruise support, to investigate oceanic mixing processes by following the radioactive tracer injected from the Chernobyl disaster.

Travel funds, participate in a SCOPE workshop, $N$-Cycling in the Marine Environment, Denmark.

Cruise support, to investigate the geochemistry of continental shelf sediments under coastal upwelling regions off Peru.

Support to investigate the sources and impacts of saxitoxins which were implicated in the deaths of humpback whales in Massachusetts Bay - Cape Cod Bay.

Support with WHOI Sea Grant, for the initial development of a flowthrough zooplankton culture system which subsequently led to full funding by NSF.

Support with WHOI Sea Grant to study the effects of sea-level rise and human development on wetland evolution and coastal eutrophication.

Support for a second year with WHOI Sea Grant to investigate the relationship between chloroliphenyl residues and levels of cytochrome P450 induction in fish.

Support for a second year with WHOI Sea Grant to study the bioaccumulation and biological effects of PCB's on marine biovalve molluscs in the field and the laboratory. Relate physological condition indicies to chlorobiphenyl concentrations. 
Biology

J. Weinberg

Geology and Geophysics

Geology and Geophysics
G. Giese

G. Giese
Tavel funds to support a sampling trip to California in order to compare west coast polychaete populations with similar species in New England.

Travel funds to attend AGU/ASLO annual meeting in New Orleans and present a paper on recent work,.

Travel funds to attend UNEP symposium in Miami, "Implications of Climate Changes in the Caribbean Regions". 
DOCUMENT LIBRARY

August 9, 1988

Distribution List for Technical Report Exchange

Attn: Stella Sanchez-Wade

Documents Section

Scripps Institution of Oceanography

Library, Mail Code C-075C

La Jolla, CA 92093

Hancock Library of Biology \&

Oceanography

Alan Hancock Laboratory

University of Southern California

University Park

Los Angeles, CA 90089-0371

Gifts \& Exchanges

Library

Bedford Institute of Oceanography

P.O. Box 1006

Dartmouth, NS, B2Y 4A2, CANADA

Office of the International

Ice Patrol

c/o Coast Guard R \& D Center

Avery Point

Groton, CT 06340

Library

Physical Oceanographic Laboratory

Nova University

8000 N. Ocean Drive

Dania, FL 33304

NOAA/EDIS Miami Library Center

4301 Rickenbacker Causeway

Miami, FL 33149

Library

Skidaway Institute of Oceanography

P.O. Box 13687

Savannah, GA 31416

Institute of Geophysics

University of Hawaii

Library Room 252

2525 Correa Road

Honolulu, HI 96822

Library

Chesapeake Bay Institute

4800 Atwell Road

Shady Side, MD 20876

MIT Libraries

Serial Journal Room 14E-210

Cambridge, MA 02139
Director, Ralph M. Parsons Laboratory

Room 48-311

MIT

Cambridge, MA 02139

Marine Resources Information Center

Building E38-320

MIT

Cambridge, MA 02139

Library

Lamont-Doherty Geological Observatory

Colombia University

Palisades, NY 10964

Library

Serials Department

Oregon State University

Corvallis, OR 97331

Pell Marine Science Library

University of Rhode Island

Narragansett Bay Campus

Narragansett, RI 02882

Working Collection

Texas A\&M University

Dept. of Oceanography

College Station, TX 77843

Library

Virginia Institute of Marine Science

Gloucester Point, VA 23062

Fisheries-Oceanography Library

151 Oceanography Teaching Bldg.

University of Washington

Seattle, WA 98195

Library

R.S.M.A.S.

University of Miami

4600 Rickenbacker Causeway

Miami, FL 33149

Maury Oceanographic Library

Naval Oceanographic Office

Bay St. Louis

NSTL, MS 39522-5001

Marine Sciences Collection

Mayaguez Campus Library

University of Puerto Rico

Mayagues, Puerto Rico 00708 


\begin{tabular}{|c|c|c|c|}
\hline $\begin{array}{l}\text { REPORT DOCUMENTATION } \\
\text { PAGE }\end{array}$ & $\begin{array}{l}\text { 1. REPORT NO. } \\
\text { WHOI-89-7 (CRC-89-1) }\end{array}$ & 2. & 3. Rocipiont's Accession No. \\
\hline \multirow{2}{*}{\multicolumn{3}{|c|}{$\begin{array}{l}\text { 4. Title and Subtitle } \\
\text { Coastal Research Center Woods Hole Oceanographic Institution } \\
\text { Report for the Period March } 1986 \text { - July } 1988\end{array}$}} & $\begin{array}{l}\text { 5. Roport Date } \\
\text { March } 1989\end{array}$ \\
\hline & & & 6. \\
\hline \multicolumn{3}{|l|}{$\begin{array}{l}\text { 7. Author(s) } \\
\text { Bruce W. Tripp }\end{array}$} & $\begin{array}{l}\text { 8. Performing Organization Ropt. No. } \\
\text { WHOI-89-7 }\end{array}$ \\
\hline \multirow{2}{*}{\multicolumn{3}{|c|}{$\begin{array}{l}\text { 9. Performing Organlzation Name and Address } \\
\text { The Woods Hole Oceanographic Institution } \\
\text { Woods Hole, Massachusetts } 02543\end{array}$}} & 10. Project/Task/Work Unit No. \\
\hline & & & $\begin{array}{l}\text { 11. Contract(C) or Grant(G) No. } \\
\text { (C) } \\
\text { (G) }\end{array}$ \\
\hline \multirow{2}{*}{\multicolumn{3}{|c|}{$\begin{array}{l}\text { 12. Sponsoring Organlzation Name and Address } \\
\text { The Richard King Mellon Foundation; The Andrew W. Mellon Foundation; } \\
\text { The Donaldson Charitable Trust; The Mobil Foundation }\end{array}$}} & $\begin{array}{l}\text { 13. Type of Report \& Poriod Covered } \\
\text { Technical Report }\end{array}$ \\
\hline & & & 14. \\
\hline
\end{tabular}

15. Supplementary Notes

This report should be cited as: Woods Hole Oceanog. Inst. Tech. Rept., WHOI-89-7. CRC-89-1.

16. Abstract (Limit: 200 words)

Activities of the WHOI Coastal Research Center during the period of March 1986 to July 1988 are briefly described. Major activities during this period include: 1 . global climate change, 2. assimilative capacity, 3. coastal instrumentation and 4. rapid response. During this period the Georges Bank book was completed and published by MTT Press.

Continuing emphasis is placed by $\mathrm{CRC}$ on fostering interdisciplinary and multi-institutional interactions. This emphasis is implemented through support of workshops, guest investigators, speakers and students.

17. Document Analysis a. Descriptors
1. Coastal Research
5. coastal erosion
2. sea-level rise
6. marine mammals
3. coastal pollution
7. climate change
4. assimilative capacity
8. Red Tide

b. Identifiers/Open-Ended Terms

c. COSATI Fleld/Group

18. Availability Statement

Approved for publication; distribution unlimited.

\begin{tabular}{|l|l|}
\hline $\begin{array}{c}\text { 19. Security Class (Thls Report) } \\
\text { UNCLASSIFIED }\end{array}$ & $\begin{array}{c}\text { 21. No. of Pages } \\
41\end{array}$ \\
\hline 20. Security Class (This Page) & 22. Price \\
\hline
\end{tabular}

